\title{
The effect of meter-scale lateral oxygen gradients at the sediment-water interface on selected organic matter based alteration, productivity and temperature proxies
}

\author{
K. A. Bogus ${ }^{1,2}$, K. A. F. Zonneveld ${ }^{1,2}$, D. Fischer ${ }^{2}$, S. Kasten ${ }^{3}$, G. Bohrmann ${ }^{1,2}$, and G. J. M. Versteegh ${ }^{2}$ \\ ${ }^{1}$ University of Bremen, Department of Geosciences, Klagenfurter Strasse, 28359 Bremen, Germany \\ ${ }^{2}$ MARUM - Center For Marine Environmental Sciences, University of Bremen, 28334 Bremen, Germany \\ ${ }^{3}$ Alfred Wegener Institute for Polar and Marine Research, Am Handelshafen 12, 27570 Bremerhaven, Germany \\ Correspondence to: K. A. Bogus (ka_bo@uni-bremen.de)
}

Received: 19 October 2011 - Published in Biogeosciences Discuss.: 25 November 2011

Revised: 17 March 2012 - Accepted: 3 April 2012 - Published: 27 April 2012

\begin{abstract}
A valid assessment of selective aerobic degradation on organic matter (OM) and its impact on OM-based proxies is vital to produce accurate environmental reconstructions. However, most studies investigating these effects suffer from inherent environmental heterogeneities. In this study, we used surface samples collected along two meterscale transects and one longer transect in the northeastern Arabian Sea to constrain initial OM heterogeneity, in order to evaluate selective aerobic degradation on temperature, productivity and alteration indices at the sediment-water interface. All of the studied alteration indices, the higher plant alkane index, alcohol preservation index, and diol oxidation index, demonstrated that they are sensitive indicators for changes in the oxygen regime. Several export production indices, a cholesterol-based stanol/stenol index and dinoflagellate lipid- and cyst-based ratios, showed significant (more than $20 \%$ ) change only over the lateral oxygen gradients. Therefore, these compounds do not exclusively reflect surface water productivity, but are significantly altered after deposition. Two of the proxies, glycerol dibiphytanyl glycerol tetraether-based $\mathrm{TEX}_{86}$ sea surface temperature indices and indices based on phytol, phytane and pristane, did not show any trends related to oxygen. Nevertheless, unrealistic sea surface temperatures were obtained after application of the $\mathrm{TEX}_{86}, \mathrm{TEX}_{86}^{L}$, and $\mathrm{TEX}_{86}^{H}$ proxies. The phytol-based ratios were likely affected by the sedimentary production of pristane. Our results demonstrate the selective impact of aerobic organic matter degradation on the lipid and palynomorph composition of surface sediments along a short lateral oxy-
\end{abstract}

gen gradient and suggest that some of the investigated proxies may be useful tracers of changing redox conditions at the sediment-water interface.

\section{Introduction}

Organic matter (OM)-based proxies are very useful tools in paleoclimatology and environmental studies of the marine realm. Unfortunately, OM-based proxies can be diagenetically modified, which produces an overprinting of the initial signals and can result in misleading reconstructions (for a review see Zonneveld et al., 2010). For an accurate interpretation of proxy results, it is therefore essential to have detailed information about the processes responsible for overprinting as well as the extent to which this might alter the original signal.

Freshly deposited OM is quickly degraded at the sedimentwater interface (SWI) during early diagenesis (Henrichs, 1992; Canuel and Martens, 1996; Prahl et al., 2000; Wakeham et al., 2002). One of the most significant variables influencing $\mathrm{OM}$ degradation is the $\mathrm{O}_{2}$ exposure time, which incorporates both the sedimentation rate and the concentration of bottom water oxygen (e.g., Cowie et al., 1995; Hedges and Keil, 1995; Hartnett et al., 1998; Hulthe et al., 1998; Hedges et al., 1999). Many OM components, such as lipid biomarkers (e.g., Hoefs et al., 2002; Sinninghe Damsté et al., 2002; Versteegh et al., 2010) and palynomorphs (e.g., Zonneveld et al., 1997, 2001; Bockelmann et al., 2007; Versteegh et al., 
2010), display varying rates of aerobic degradation, as some are intrinsically more labile (e.g., Sun and Wakeham, 1994; Wakeham et al., 2002; Zonneveld et al., 2008). This is important as biomarkers and palynomorphs are widely used to reconstruct oceanographic conditions. However, in studies of marine sediments, it is difficult to separate the effects of selective aerobic degradation from other factors, such as differences in upper water column conditions (van der Weijden et al., 1999), wind transported material (Witte and Pfannkuche, 2000), sediment accumulation rate (Hedges and Keil, 1995), as well as winnowing (Pedersen et al., 1992), lateral transport (Calvert et al., 1995; Mollenhauer et al., 2007; 2008) and advection, and water depth (Wakeham et al., 2002; Wuchter et al., 2006). These all can influence the composition of OM settling on the sea floor and therefore complicate interpretations regarding the effect of oxygen (Hedges and Keil, 1995).

In this study, we investigate changes in biomarker- and palynomorph-based proxy ratios as a result of laterally increasing oxygen concentrations at the SWI on the Pakistan continental margin (northeastern Arabian Sea), where the bottom water oxygen concentration is one suggested factor that influences OM preservation (e.g., Paropkari et al., 1992, 1993; Cowie et al., 1999; Keil and Cowie, 1999; van der Weijden et al., 1999; Schulte et al., 2000). The higher plant alkane index (HPA; Westerhausen et al., 1993), alcohol preservation index (API; Cacho et al., 2000), and diol oxidation index (DOXI; Ferreira et al., 2001) have previously been used to indicate sediment alteration and oxygenation changes in the sedimentary record. We evaluate whether they are also sensitive indicators of changes at the SWI. Additionally, some biomarkers commonly used to indicate changes in export production, such as phytol, cholesterol, and dinosterol (Volkman et al., 1998), were shown to be more rapidly degraded in an oxygenated environment (e.g., Schulte et al., 2000). In order to determine whether this degradation is selective, we incorporate them into indices with related refractory compounds, such as pristane and phytane, cholestanol, and dinostanone and dinosterone, respectively (after Nishimura and Koyama, 1977; McCaffrey et al., 1991; Mouradian et al., 2007). Another proxy for illustrating changes in export production is the ratio between gonyaulacoid and peridinioid organic-walled dinoflagellate resting cysts (e.g., Harland, 1973; McCarthy et al., 2000). However, the gonyaulacoid species are more resistant to aerobic degradation than the peridinioid species, which are sensitive to oxygen exposure (e.g., Zonneveld et al., 1997, 2001; Combourieu-Nebout et al., 1998; Versteegh and Zonneveld, 2002). Here, we compare the resistant gonyaulacoid cysts to the sensitive peridinioid cysts, together with the sensitive cysts of the Polykrikos species, in order to determine the extent this ratio may be affected. Finally, we investigate marine isoprenoidal archaeal glycerol dibiphytanyl glycerol tetraether (GDGT) distribution (Karner et al., 2001; Wuchter et al., 2005; Menzel et al., 2006), which is the basis for a sea surface temperature (SST) proxy based on the number of GDGT cyclopentane moieties (e.g., Schouten et al., 2002; Kim et al., 2008, 2010). There is conflicting evidence for the influence of selective aerobic degradation on GDGTs with some studies suggesting no selective degradation (e.g., Sinninghe Damsté et al., 2002; Schouten et al., 2004; Kim et al., 2009), and others indicating that differences in lability between the moieties are possible (e.g., Shah et al., 2008; Huguet et al., 2009). In order to provide more clarity to this issue, we investigate the possible effect of early oxidation on GDGT-based indices.

As the effects of selective aerobic degradation are best studied on samples with similar initial OM compositions, we utilize surface sediment samples collected along three transects that, when used in conjunction, allow us to constrain the uncertainty associated with OM heterogeneity. The first transect encompasses the large, stable, intermediate depth (150-1300 m; e.g., Breuer et al., 2009) oxygen minimum zone (OMZ) and oxygenated deeper water. Two additional transects include meter-scale methane seep sites in this region (e.g. von Rad et al., 1996; Fischer et al., 2011). One seep transect is located at the lower transition of the OMZ and is used to record the impact of the seep environment on the OM composition. The other seep transect is located below the OMZ in well-oxygenated bottom waters, where oxygen levels presumably increase with distance from the gas outflow. The active advection of vent fluids at a seep site reduces the oxygen penetration depth and the $\mathrm{O}_{2}$ concentration at the SWI (Aharon and Fu, 2003). This results in a short lateral oxygen gradient extending from just adjacent to the active venting towards the periphery of the seep site. Essentially, the meter-scale seep transects serve to constrain environmental variability that may affect $\mathrm{OM}$ composition along the longer OMZ transect, while the influence of OM contributed by the seep biomass and possible complications from anaerobic degradation (e.g., Canfield et al., 1993; Grossi et al., 2001) via bacterial sulfate reduction (e.g., Jørgensen, 1982; Lückge et al., 1999; Jørgensen and Kasten, 2006) are addressed through the comparison of the seep transects to each other, and from the seep transects to the OMZ transect. By utilizing the three transects in this manner to limit other environmental factors, we are able to evaluate the influence of laterally varying oxygen concentrations on organic-matter based proxies for sediment alteration/oxygenation, export production and temperature.

\section{Regional setting}

In the study area, two monsoon seasons, the boreal winter northeast monsoon (NEM) and the stronger southwest monsoon (SWM) in the summer, result from land-sea pressure gradients due to differential summer heating of the Asian continent. This produces seasonally-reversing wind conditions, which induce high annual primary productivity (Wyrtki, 1973; Qasim, 1982) along the coast and in the open 
Table 1. Sample location descriptions and oxygen classification scheme

\begin{tabular}{|c|c|c|c|c|c|c|c|c|c|c|}
\hline Sample & $\begin{array}{l}\text { Referred } \\
\text { in text as }\end{array}$ & $\begin{array}{l}\text { Latitude } \\
\text { (N) }\end{array}$ & $\begin{array}{l}\text { Longitude } \\
\text { (E) }\end{array}$ & $\begin{array}{l}\text { Water } \\
\text { depth (m) }\end{array}$ & Transect & $\begin{array}{l}\text { Sample } \\
\text { location }\end{array}$ & {$\left[\mathrm{O}_{2}\right] \mathrm{mll}^{-1 *}(\mu \mathrm{M})$} & $\mathrm{Mn}^{2+}$ at SWI & $\begin{array}{l}\text { Oxygen } \\
\text { classification }\end{array}$ & Based on \\
\hline GeoB 12312 & OMZ-hypoxic & $24^{\circ} 53^{\prime}$ & $63^{\circ} 01^{\prime}$ & 655 & OMZ & OMZ core & $0.02(<1 \mu \mathrm{M})$ & - & hypoxic & $\begin{array}{l}\text { CTD of the } \\
\text { station, }\end{array}$ \\
\hline GeoB 12321 & OMZ-suboxic & $24^{\circ} 46^{\prime}$ & $62^{\circ} 59^{\prime}$ & 1425 & $\mathrm{OMZ}$ & $\begin{array}{l}\text { OMZ lower } \\
\text { transition }\end{array}$ & $0.55(36 \mu \mathrm{M})$ & - & suboxic & $\begin{array}{l}\mathrm{O}_{2} \text { penetra- } \\
\text { tion depth, }\end{array}$ \\
\hline GeoB 12331 & OMZ-oxic & $24^{\circ} 11^{\prime}$ & $62^{\circ} 46^{\prime}$ & 2830 & $\mathrm{OMZ}$ & $\begin{array}{l}\text { well below } \\
\text { OMZ }\end{array}$ & $2.55(\sim 330 \mu \mathrm{M})$ & - & oxic & $\mathrm{Fe}^{2+}$ \\
\hline GeoB 12326-13 & $\begin{array}{l}\text { below-OMZ- } \\
\text { seep } 1\end{array}$ & $24^{\circ} 11^{\prime}$ & $62^{\circ} 44^{\prime}$ & 2875 & $\begin{array}{l}\text { below OMZ } \\
\text { seep }\end{array}$ & $\begin{array}{l}\text { adjacent to gas } \\
\text { orifice }\end{array}$ & - & yes & hypoxic & $\begin{array}{l}\mathrm{Mn}^{2+} \\
\text { profile }\end{array}$ \\
\hline GeoB 12326-9 & $\begin{array}{l}\text { below-OMZ- } \\
\text { seep } 2\end{array}$ & $24^{\circ} 11^{\prime}$ & $62^{\circ} 44^{\prime}$ & 2875 & $\begin{array}{l}\text { below OMZ } \\
\text { seep }\end{array}$ & $\begin{array}{l}50 \mathrm{~cm} \text { from gas } \\
\text { orifice, clam field }\end{array}$ & - & no & suboxic & $\begin{array}{l}\mathrm{Mn}^{2+} \\
\text { profile }\end{array}$ \\
\hline GeoB 12326-7 & $\begin{array}{l}\text { below-OMZ- } \\
\text { seep } 3\end{array}$ & $24^{\circ} 11^{\prime}$ & $62^{\circ} 44^{\prime}$ & 2875 & $\begin{array}{l}\text { below OMZ } \\
\text { seep }\end{array}$ & $\begin{array}{l}1 \mathrm{~m} \text { from gas ori- } \\
\text { fice, ambient sedi- } \\
\text { ment border }\end{array}$ & $2.55(\sim 330 \mu \mathrm{M})$ & - & oxic & $\begin{array}{l}\text { CTD of the } \\
\text { station }\end{array}$ \\
\hline GeoB 12328-6 & OMZ-seep 1 & $24^{\circ} 50^{\prime}$ & $63^{\circ} 01^{\prime}$ & 1025 & OMZ seep & bacterial mat & $0.07(\sim 3 \mu \mathrm{M})$ & - & hypoxic & $\begin{array}{l}\text { CTD of the } \\
\text { station }\end{array}$ \\
\hline GeoB 12328-2 & OMZ-seep 2 & $24^{\circ} 50^{\prime}$ & $63^{\circ} 01^{\prime}$ & 1025 & OMZ seep & $\begin{array}{l}15 \mathrm{~cm} \text { from mat, } \\
\text { clam border }\end{array}$ & $0.07(\sim 3 \mu \mathrm{M})$ & - & hypoxic & \\
\hline GeoB 12328-4 & OMZ-seep 3 & $24^{\circ} 50^{\prime}$ & $63^{\circ} 01^{\prime}$ & 1025 & OMZ seep & $\begin{array}{l}75 \mathrm{~cm} \text { from } \\
\text { central habitat, } \\
\text { clam field }\end{array}$ & $0.07(\sim 3 \mu \mathrm{M})$ & - & hypoxic & \\
\hline
\end{tabular}

* As measured by CTD profiling of the deep water.

ocean region through upwelling (during SWM) and convective mixing (during NEM) (Bauer et al., 1991; Madhupratap et al., 1996; Prassana Kumar et al., 2001). Abundant OM in the upper water column due to the high primary production leads to a high rate of oxygen consumption as a result of OM degradation. Together with the inflow of $\mathrm{O}_{2}$-poor intermediate waters, these cause a stable, intermediate depth OMZ that has existed for the past 7000 years (Shapiro and Meschanov, 1991; Olson et al., 1993; von Rad et al., 1999). Current estimates place the OMZ between $\sim 150-1000 \mathrm{~m}$ water depth, although there is some variability as to the depths of the upper and lower boundaries (Brand and Griffiths, 2009; Breuer et al., 2009). The extent of the OMZ in this study, as measured by CTD profiling, is shown in Fig. 1. Average OM export production for the Pakistan continental margin is approximately $70 \mathrm{~g} \mathrm{C} \mathrm{m}^{-2} \mathrm{yr}^{-1}$ with a sedimentation rate on the slope of up to $1 \mathrm{~mm} \mathrm{yr}^{-1}$ (von Rad et al., 1995, 1999; van der Weijden et al., 1999). Sedimentary OM primarily reflects marine input (e.g., Paropkari et al., 1992; Cowie et al., 1999; Lückge et al., 1999; Schulte et al., 2000), although, there is some seasonal terrestrial influx of organic rich mud from the Shadi and Hingol rivers (Bohrmann et al., 2008). The Makran accretionary prism contains numerous cold seeps, which are areas of fluid and gas emissions from the sea floor (von Rad et al., 1995, 1996). R/V Meteor cruise M74/2-3, during which the samples used in this study were retrieved, was an interdisciplinary cruise specifically scheduled to explore the Makran continental margin for further fluid escape structures (Bohrmann et al., 2008) driven by tectonically induced overpressure (Ding et al., 2010). Coupled to the upward gas migration at seep sites are chemosynthetic communities that rely on the supply of reduced compounds such as hydrogen sulfide and methane (Suess et al., 1985). Microbial mats composed of large sulfide-oxidizing bacteria (Beggia- toa and Marithioploca spp.) and clam fields (Calyptogena spp.) associated with such seep sites have been specifically found here (e.g., von Rad et al., 1995, 1996; Bohrmann et al., 2008; Fisher et al., 2011). The biogeography of the seep sites is to some degree controlled by the active fluid and gas expulsion into the water column as well as oxygen availability (Roberts and Carney, 1997; Fischer et al., 2011). Thus, these seep sites can encompass localized areas of anoxia at the SWI in otherwise oxygenated bottom waters (Aharon and $\mathrm{Fu}$, 2000), such as below the OMZ (von Rad et al., 1996). The two seep fields sampled for this study are shown in Fig. 2.

\section{Material and methods}

\subsection{Material}

Surface sediments were retrieved along three transects during R/V Meteor cruise M74/3 during the 2007 fall intermonsoon (Bohrmann et al., 2008). In the study area, CTD casts identified the lowest oxygen concentrations between $350-750 \mathrm{~m}$ water depth with $900-1200 \mathrm{~m}$ containing slightly higher $\mathrm{O}_{2}$ content and well-ventilated waters found below $1600 \mathrm{~m}$ (Fig. 1; Table 1). The CTD profiles were used for the identification of the OMZ and for a tentative assignment of the oxygen regimes at each studied transect.

\subsubsection{OMZ transect}

Three multi-cores were retrieved along a kilometer-scale transect starting within the core OMZ (GeoB 12312; $0.02 \mathrm{mll}^{-1} \quad \mathrm{O}_{2} \quad[<1 \mu \mathrm{M}] ; 655$ meters below sea level [m b.s.1.]) into the transition zone (GeoB 12321; $0.55 \mathrm{ml} \mathrm{l}^{-1}$ $\mathrm{O}_{2}[36 \mu \mathrm{M}] ; 1425 \mathrm{~m}$ below sea level [m b.s.l.]) and extending into the oxic zone below (GeoB 12331; $2.55 \mathrm{mll}^{-1} \mathrm{O}_{2}$ 
a)

$61^{\circ} \mathrm{E} \quad 63^{\circ} \mathrm{E} \quad 65^{\circ} \mathrm{E}$

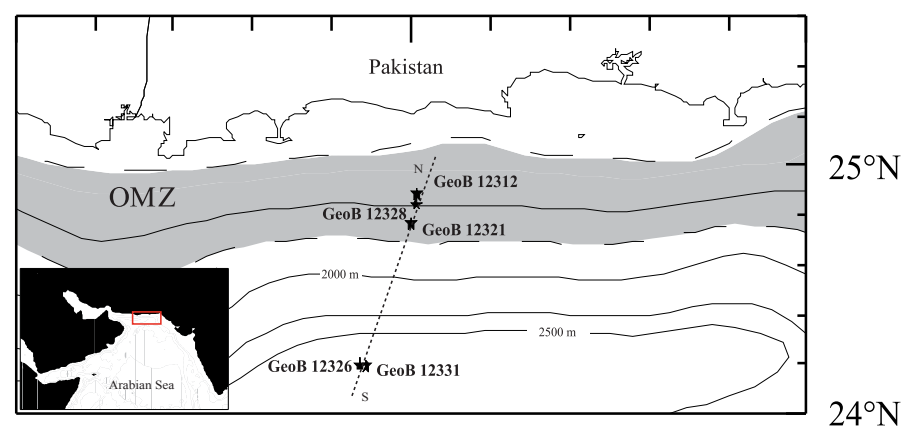

b)

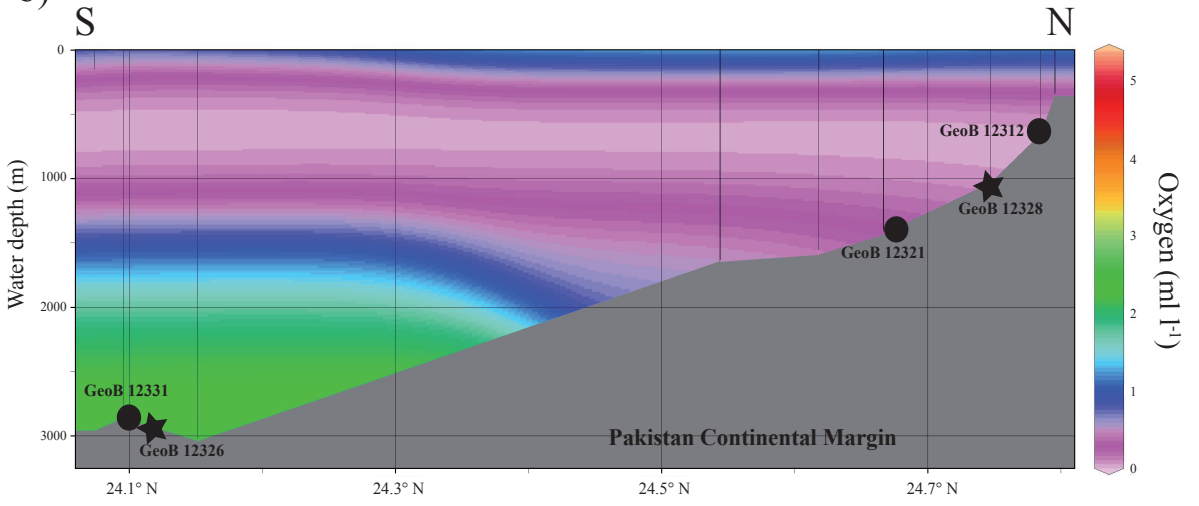

Fig. 1. Map showing (a) sample locations along the Pakistan continental margin in relation to the intermediate depth oxygen minimum zone (OMZ) (b) water column oxygen concentrations, as measured by CTD profiling, compared to the sample locations. Circles indicate multi-core samples, and comprise the OMZ transect, and stars denote push core locations, which comprise the two seep transects.

$[\sim 330 \mu \mathrm{M}] ; 2830 \mathrm{~m}$ b.s.1.). This series of samples is hereafter referred to as the OMZ transect (Fig. 1; Table 1), and the samples are tentatively characterized as OMZ-hypoxic (GeoB 12312), OMZ-suboxic (GeoB 12321) and OMZ-oxic (GeoB 12331). Only the uppermost unconsolidated sediment layer $(<1 \mathrm{~cm})$ was sampled and all of the sediments are composed of clay to silty clay material. They were not retrieved near areas of active seeping and thus represent background sediments of detrital OM-based ecosystems. OMZhypoxic contained finely laminated layers and no indications of bioturbation, whereas OMZ-suboxic and OMZ-oxic appeared more homogenized, most likely due to bioturbation (Bohrmann et al., 2008). Subsamples for palynomorph and biomarker analyses were sealed air tight and either stored at $4{ }^{\circ} \mathrm{C}$, or under under argon and at $-20^{\circ} \mathrm{C}$, respectively, until analysis.

\subsubsection{Seep transects}

Two seep fields (GeoB 12328 and GeoB 12326; Fig. 1; Table 1) were sampled using the remotely operated vehicle (ROV) QUEST 4000 (Bohrmann et al., 2008). This technique allowed us to know the exact core location as well as view the surrounding environment (Fig. 2). The CTD bottom water oxygen measurements from the two push core stations demonstrated that site GeoB 12328 was located in the transitional OMZ zone $\left(0.07 \mathrm{mll}^{-1} \mathrm{O}_{2}[\sim 3 \mu \mathrm{M}] ; 1025 \mathrm{~m}\right.$ b.s.l. $)$ and site GeoB 12326 was located in well-oxygenated bottom waters $\left(2.55 \mathrm{mll}^{-1} \mathrm{O}_{2}[\sim 330 \mu \mathrm{M}] ; 2875 \mathrm{mbsl}\right)$ (Fig. 1; Table 1). Subsequently, the two seep fields are referred to as OMZ-seep (GeoB 12328) and below-OMZ-seep (GeoB 12326). Three successive push core samples comprise the OMZ-seep transect: GeoB 12328-6 (OMZ-seep 1) was retrieved at the edge of the central bacterial mat, GeoB 123282 (OMZ-seep 2) was $15 \mathrm{~cm}$ distance away from the bacterial mat where bubbles of free gas escape at the sea floor, and GeoB 12328-4 (OMZ-seep 3) at about $75 \mathrm{~cm}$ from the active seeping and within the clam field (Fig. 2a; Table 1). As well, three successive push core samples comprise the belowOMZ-seep: GeoB 12326-13 (below-OMZ-seep 1) was just adjacent to active seeping, GeoB 12326-9 (below-OMZ-seep 2) was $50 \mathrm{~cm}$ away from the central gas orifice and within the area of small clams, and GeoB 12326-7 (below OMZ seep 3) was $1 \mathrm{~m}$ further away at the edge of the small clams and ambient sea floor (Fig. 2b; Table 1). As with the OMZ transect, only the uppermost unconsolidated sediment layer $(<1 \mathrm{~cm})$ was sampled. When only the seep transect is stated 
a) OMZ-seep transect (GeoB 12328)
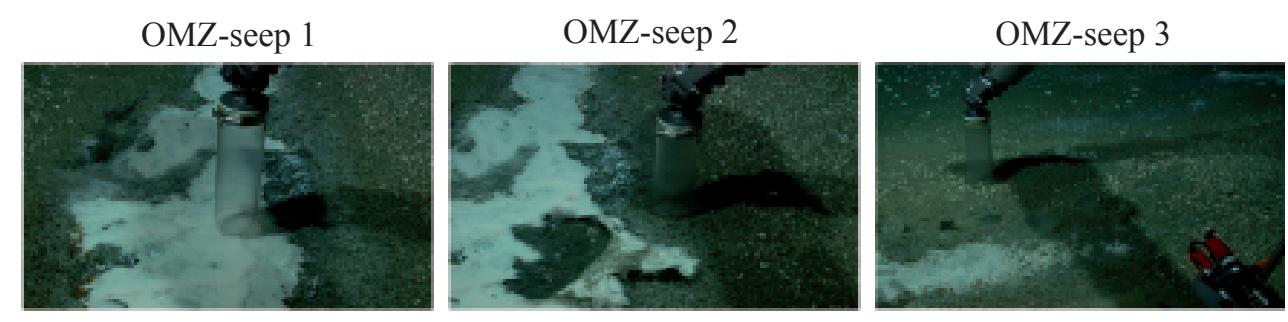

b) below-OMZ-seep transect (GeoB 12326)
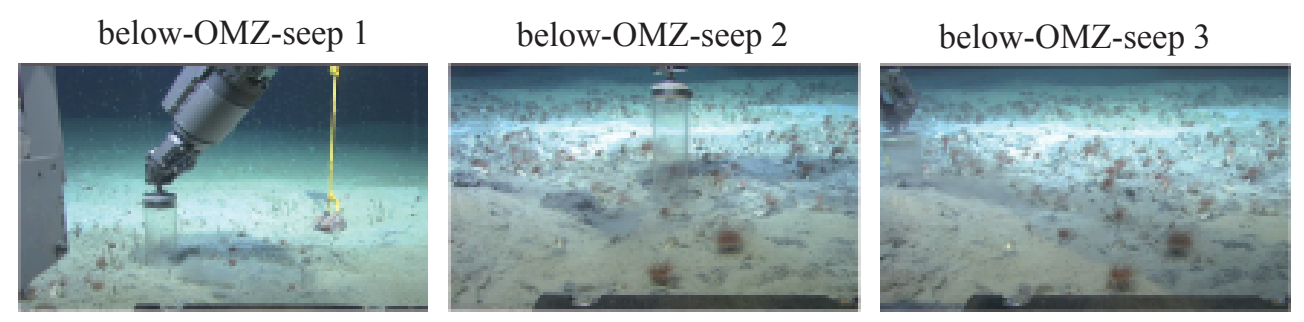

Fig. 2. High resolution photographs taken by the ROV QUEST 4000 showing the surrounding environment of the individual push cores retrieved along the two seep transects (a) OMZ-seep (GeoB 12328), and specific samples OMZ-seep 1 (GeoB 12328-6), OMZ-seep 2 (GeoB 12328-2), and OMZ-seep 3 (GeoB 12328-4), (b) below-OMZ-seep (GeoB 12326), and specific samples below-OMZ-seep 1 (GeoB 1232613), below-OMZ-seep 2 (GeoB 12326-9), and below-OMZ-seep 3 (GeoB 12326-7).

(i.e., OMZ-seep or below-OMZ-seep), this refers to all of the push cores retrieved at that respective site. All subsamples for biomarker and palynomorph analysis were stored under argon and at $-20^{\circ} \mathrm{C}$.

\subsection{Methods}

\subsubsection{Geochemical parameters}

Ex situ pore water oxygen was measured on replicate whole cores to OMZ-hypoxic, OMZ-suboxic, and OMZ-oxic with a FIBOX3 oxygen sensor coupled to a micromanipulator. This was performed in order to gain more accurate information, compared to the CTD profiles, as to the oxygen conditions at the SWI as well as values in the upper sediments. The cores were allowed to acclimate to ambient temperature and then the $\mathrm{O}_{2}$ probe was lowered quickly to the measurement depth and left until the $\mathrm{O}_{2}$ reading became stable. Measurements were taken at $2.5 \mathrm{~mm}$ intervals and in triplicate. The $\mathrm{O}_{2}$ penetration depth was compared to pore water iron $\left(\mathrm{Fe}^{2+}\right)$ concentrations, as a way to confirm the redox boundary. For this purpose, pore water was extracted at $1 \mathrm{~cm}$ intervals on board via rhizons (pore size $0.1 \mu \mathrm{M}$ ) according to the method of Seeberg-Elverfeldt et al. (2005). Subsamples $(1 \mathrm{ml})$ were complexed with $50 \mu \mathrm{l}$ of "Ferrospectral" and measured photometrically. For the below-OMZ-seep, manganese $\left(\mathrm{Mn}^{2+}\right)$ pore water concentrations were measured at $1 \mathrm{~cm}$ intervals from two push cores retrieved from the same locations as below-OMZ-seep 1 (central habitat, active gas ebullition) and below-OMZ-seep 2 (within clam field). A pore water subsample for cation analysis was diluted 1:10 with $1 \mathrm{M} \mathrm{HNO}_{3}^{-}$and stored at $4{ }^{\circ} \mathrm{C}$. Samples were analyzed for $\mathrm{Mn}^{2+}$ concentrations with an ICP-OES (IRIS Intrepid, Thermo Electron). Standards were prepared from single element stock solutions in $1 \mathrm{M} \mathrm{HNO}_{3}^{-}$to avoid matrix effects. Replicate measurements gave an error of $\leq 3 \%$.

\subsubsection{Lipid biomarkers}

Freeze dried sediment samples $(1-10 \mathrm{~g})$ were ground with an agate mortar and pestle, and the total lipid extract (TLE) was extracted using an Dionex 200 ASE (Accelerated Solvent Extractor) with methanol $(\mathrm{MeOH})$ and dicholoromethane (DCM) $\left(9: 1 \mathrm{v}: \mathrm{v} ; 3\right.$ cycles of 5 min duration each) at $100^{\circ} \mathrm{C}$ and $7.6 \times 10^{6} \mathrm{~Pa}$. A small aliquot $(100 \mu \mathrm{l})$ of the TLE was evaporated under $\mathrm{N}_{2}$ to dryness and then redissolved in $100 \mu \mathrm{l} n$-hexane and propanol (99:1 v:v) for GDGT analysis following the procedure of Liu et al. (2011), modified after Hopmans et al. (2000). Briefly, a ThermoFinnigan Surveyor high performance liquid chromatography (HPLC) system was used at $30^{\circ} \mathrm{C}$, a flow rate of $1 \mathrm{ml} \mathrm{min}^{-1}$, and separation was achieved with an Econosphere $\mathrm{NH}_{2}$ column $(250 \times 4.6 \mathrm{~min}$; Alltech, Germany). The gradient used was the same as Liu et al. (2011). The HPLC was coupled to a ThermoFinnigan LCQ Deca XP Plus ion trap mass spectrometer via an atmospheric pressure chemical ionization (APCI) interface. These settings were also the same as described in Liu et al. (2011). Relative GDGT concentrations were 
acquired by integrating the appropriate peak areas of their $(\mathrm{M}+\mathrm{H})^{+}$and $(\mathrm{M}+\mathrm{H})^{+}+1$ mass chromatograms.

Another aliquot $(500 \mu \mathrm{l})$ of the TLE was partitioned into a $n$-hexane soluble fraction and a DCM soluble fraction. The hexane soluble fraction was then derivatized with $50 \mu \mathrm{l}$ Bis(trimethylsilyl)trifluoroacetamide (BSTFA) and pyridine $\left(60{ }^{\circ} \mathrm{C}, 1 \mathrm{~h}\right)$ to produce trimethylsilylated alcohols. An internal standard mix $(5 \mu \mathrm{g})$ containing $\mathrm{C}_{36} n$-alkane and 1nonadecanol was added before derivatization. Samples were then analyzed using an Agilent Technologies 7890A Gas Chromatograph (GC) equipped with a splitless injector and a HP-5MS column (i.d. $0.25 \mathrm{~mm}$; film thickness $0.25 \mu \mathrm{m}$ ) operated at a flow rate of $1 \mathrm{ml} \mathrm{min}^{-1}$. Helium was used as the carrier gas. The temperature program was as follows: $70^{\circ} \mathrm{C}$ (1 min), then $60-310^{\circ} \mathrm{C}$ at $4^{\circ} \mathrm{C} \mathrm{min}^{-1}$ and $320^{\circ} \mathrm{C}(21 \mathrm{~min})$. The GC was coupled to a quadripole mass spectrometer (MS) (597C VL MSD Triple Axis Detector) operated at $70 \mathrm{eV}$ and a scan range of 50-800 AMU. Compounds were identified based on relative retention times and indices, and mass spectra. In general, they were quantified from comparing their peak areas in the total ion current with internal standards. Due to co-elution, the $\mathrm{C}_{30}$ 1, 15-diols and keto-ols were quantified by the analysis of characteristic mass spectra fragments and then calibration to an internal standard. The specific fragments were the $\mathrm{m} / \mathrm{z} 387$ and 328 for the diols and keto-ols (after Versteegh et al., 2000), respectively, and the $m / z 103$ of the 1 -nonedecanol standard. The relative response factors were assumed to be 1 ; hence our data are only semi-quantitative. Since we were interested primarily in the relative changes of proxy ratios between samples, this analysis was sufficient.

\subsubsection{Dinoflagellate cysts}

Sample material $(\sim 0.3 \mathrm{~g})$ was oven dried $\left(60^{\circ} \mathrm{C} ; 24 \mathrm{~h}\right)$, weighed and treated with cold $10 \% \mathrm{HCl}(24 \mathrm{~h})$ to remove carbonates and $38 \% \mathrm{HF}$ (48 h after $90 \mathrm{~min}$ agitation) to remove silicates, then neutralized with $10 \% \mathrm{KOH}$. Care was taken to ensure that the solutions never became alkaline. The samples were briefly put in an ultrasonic bath $(<1 \mathrm{~min})$ and sieved over a $20 \mu \mathrm{m}$ precision sieve (Stork Veco; mesh 317 ). Samples were centrifuged (3200 rpm; $6 \mathrm{~min}$ ) and concentrated to $1.0 \mathrm{ml}$, after which $50 \mu \mathrm{l}$ were mounted in glycerin jelly and sealed on a glass slide with paraffin wax. Entire slides were counted blind for dinoflagellate cysts with a Zeiss Axioskop light microscope. At least 200 whole specimens were counted. If necessary, additional slides were counted entirely. Taxonomy was based on Fensome and Williams (2004) and Matsuoka et al. (2009). Dinoflagellate cyst taxa were divided into two groups, gonyaulacoid (G-cysts), and peridinioid and cysts of Polykrikos (P-cysts) (Table 2). Quantification was performed via the volumetric method (e.g., Dale, 1976; Holzwarth et al., 2007).
Table 2. Gonyaulacoid (G) along with peridinioid and cysts of Polykrikos (P) dinoflagellate cyst species identified in this study. These species correspond generally to those that are more resistant to oxidation (G-cysts) and those that are more sensitive (P-cysts), based on Zonneveld et al. (2007).

\begin{tabular}{ll}
\hline P-cysts & G-cysts \\
\hline Brigantedinium spp. & Bitectatodinium spongium \\
Cyst of Diplopelta parva & Impagidinium aculeatum \\
Cyst of Polykrikos kofoidii & Impagidinium paradoxum \\
Cyst of Protoperidinium americanum & Impagidinium patulum \\
Cyst of Protoperidinium monospinum & Impagidinium sphaericum \\
Cyst of Protoperidinium stellatum & Impagidinium spp. \\
Dubridinium spp. & Lingulodinium machaerophorum \\
Echinidinium aculeatum & Nematosphaeropsis labyrinthus \\
Echinidinium bispiniformum & Operculodinium centrocarpum \\
Echinidinium granulatum & Operculodinium israelianum \\
Echinidinium transparantum & Operculodinium longispinigerum \\
Echinidinium delicatum & cyst Pentapharsodinium dalei \\
Echinidinium spp. & Polysphaeridium zoharyi \\
Leipokatium invisitatum & Spiniferites membranaceous \\
Lejeunecysta oliva & Spiniferites mirabilis \\
Lejeunecysta sabrina & Spiniferites pachydermus \\
Lejeunecysta spp. & Spiniferites ramosus \\
Quinquecuspis concreta & Spiniferites spp. \\
Selenopemphix nephroides & \\
Selenopemphix quanta & \\
Stelladinium robustum & \\
Trinovantedinium applanatum & \\
Votadinium calvum & \\
Xandarodinium xanthum & \\
\hline
\end{tabular}

\subsubsection{Proxy ratio calculations}

A proxy trend in this study is defined as a consistent increase or decrease along successive samples within a transect. All specific proxy definitions and formulae are depicted in Table 3. Additionally, all raw data used for the calculation of the indices (lipid biomarker concentrations, GDGT peak areas, and dinoflagellate cyst counts) can be found in the Supplement.

The alteration and oxygenation proxies include the HPA index that utilizes the $\Sigma \mathrm{C}_{24-28}$ even $n$-alcohols divided by the $\Sigma C_{27-31}$ odd $n$-alkanes (Westerhausen et al., 1993), and the API, which uses only $n$-hexacosanol and $n$-nonacosane (Cacho et al., 2000). The HPA and API ratios will exhibit decreasing values if their respective $n$-alcohols are selectively degraded relative to the $n$-alkanes. The DOXI involves the concentration of 1,15-long chain alkyl diols divided by the keto-ols (Ferreira et al., 2001). This proxy assumes that the keto-ols are mainly oxidation products of the diols; thus, higher ratio values indicate higher degradation of the diols relative to the keto-ols. We initially calculated the DOXI with the dominant $\mathrm{C}_{30}$ isomers; the predominance of this isomer was reported previously in Arabian Sea sediments (e.g., Smallwood and Wolff, 2000; Wakeham et al., 2002). Where possible, the ratio was also calculated using the $\mathrm{C}_{32}$ isomers.

The productivity indices are based on phytol, cholesterol and dinosterol and their degradation products, along with the 


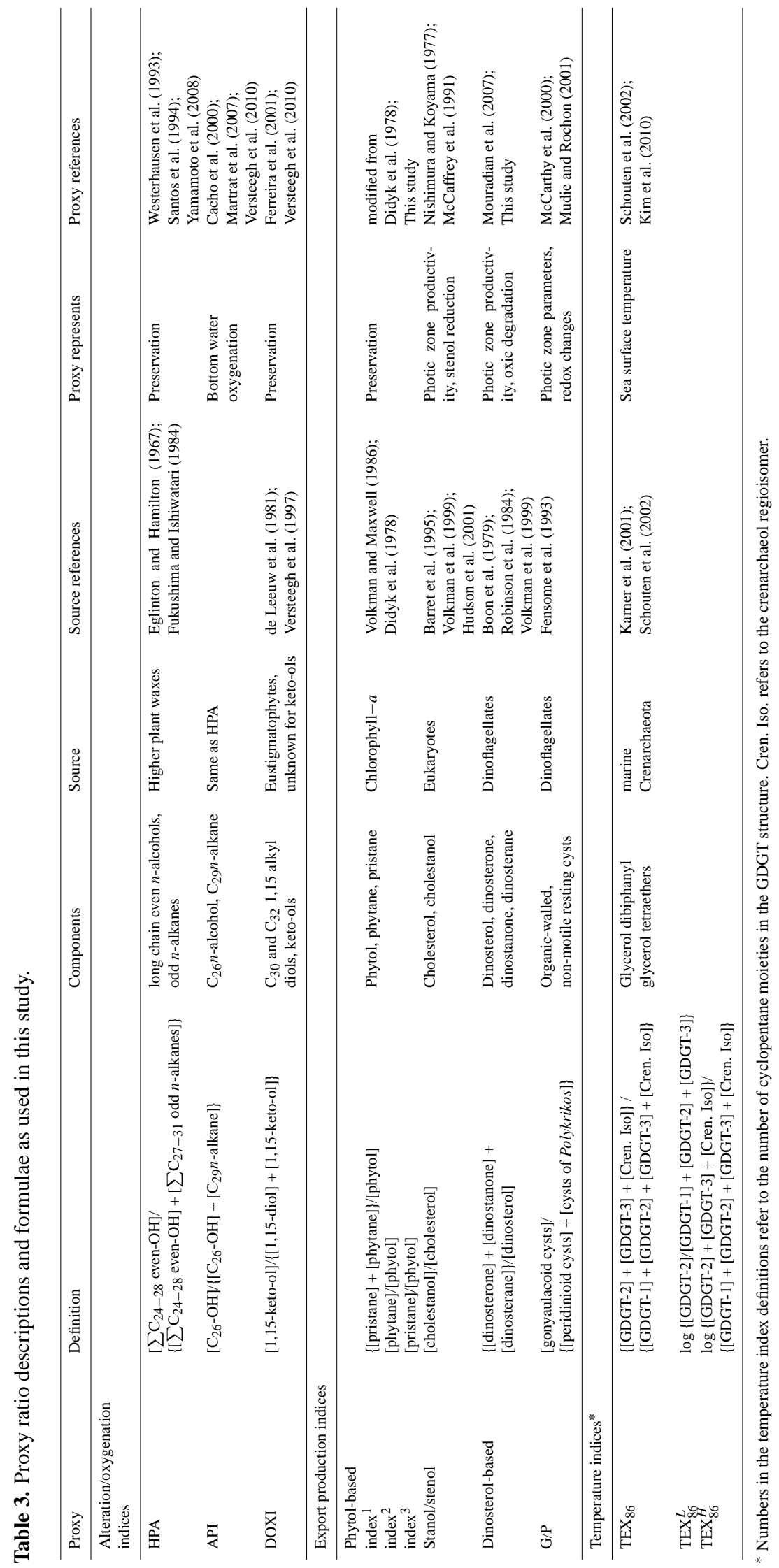



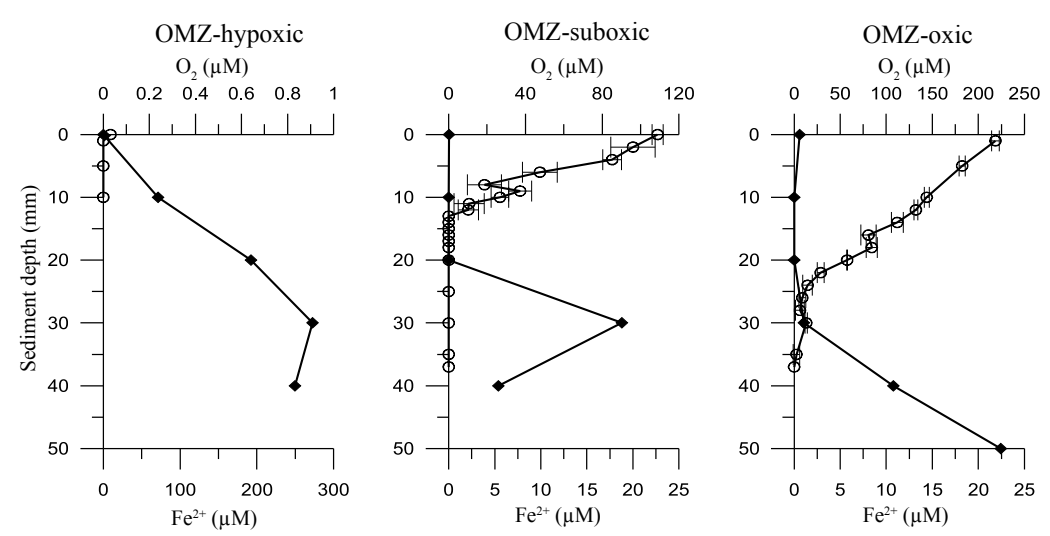

Fig. 3. Pore water oxygen (open circles) and $\mathrm{Fe}^{2+}$ (closed diamonds) values measured in the OMZ transect multi-cores to show the position of the oxygen penetration depth. All $\mathrm{O}_{2}$ values are shown with error bars depicting one standard deviation. Please note the different scales for both the $\mathrm{O}_{2}$ and $\mathrm{Fe}^{2+}$ values.

dinoflagellate cysts. For the three phytol-based indices, significant preferential degradation of phytol would result in overall higher ratio values as pristane and phytane are generally considered compounds produced via degradation of phytol (e.g., Didyk et al., 1978). Both pristane and phytane are used in index ${ }^{1}$, whereas only phytane or pristane are used in the second and third indices, respectively. The cholesterolbased stanol/stenol index will show an increase with more efficient cholesterol oxidation. The dinosterol-based index compares dinosterol with other dinoflagellate-derived degradation products, dinosterone, dinostanone, and dinosterane ( $\Sigma$ dinoflagellate lipids). Thus, increases in the proxy indicate faster removal of dinosterol. Although the original definition of the G/P ratio is based on the number of species (Harland, 1973), in this study we used the quantity of Gand P-cysts in each sample because the small spatial scale of our transects made differences in species numbers highly unlikely. With preferential degradation of P-cysts, the ratio will increase along a transect.

The temperature indices are based on the isoprenoid GDGT distribution. The abundance of different GDGT moieties can be correlated to temperature using the GDGTs with one to three cyclopentane moieties and the crenarchaeol regioisomer, which contains four cyclopentane moieties and one cyclohexane moiety (Wuchter et al., 2004; Schouten et al., 2007). Three indices are calculated based on Kim et al. (2010): $\mathrm{TEX}_{86}, \mathrm{TEX}_{86}^{L}, \mathrm{TEX}_{86}^{H}$. The $\mathrm{TEX}_{86}^{L}$ and $\mathrm{TEX}_{86}^{H}$ are postulated to be more appropriate for cooler and warmer temperatures, respectively, although previous work has demonstrated that both seem to be reliable in the Arabian Sea (Kim et al., 2010). From each of these indices, sea surface temperatures (SST) were calculated after Kim et al. (2010), using the linear calibration Eqs. (5), (8), and (10) for $\mathrm{TEX}_{86}, \mathrm{TEX}_{86}^{L}$, and $\mathrm{TEX}_{86}^{H}$, respectively (see text of Table 4 for the equations). Changes in the distribution of the GDGTs are thus reflected in the index values and calculated SSTs.
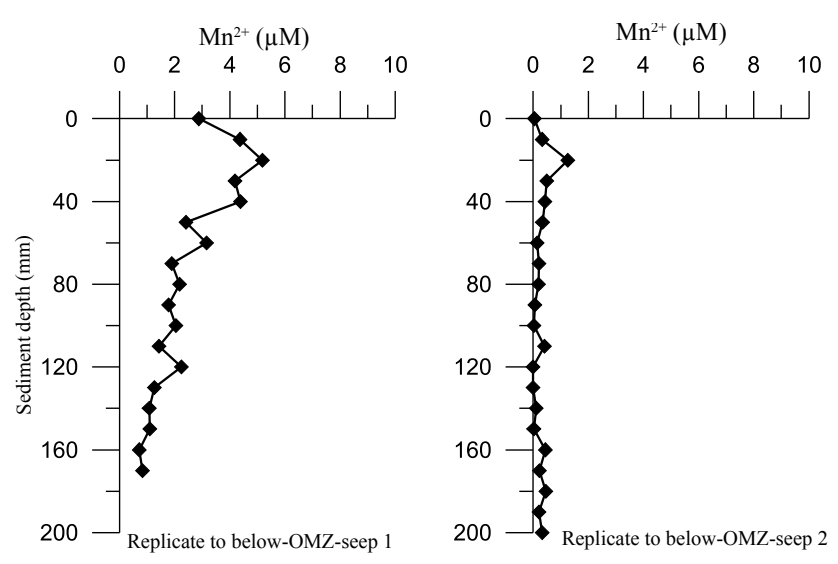

Fig. 4. $\mathrm{Mn}^{2+}$ pore water concentrations measured on two push cores that were taken from similar positions ("replicate") to belowOMZ-seep 1 (adjacent to gas orifice) and below-OMZ 2-seep (within the small clam field).

\section{Results}

\subsection{Oxygen content at the SWI}

The $\mathrm{O}_{2}$ penetration depth in the sediments increases along the OMZ transect from undetectable (OMZ-hypoxic) to a maximum of about $25 \mathrm{~mm}$ (OMZ-oxic), and is consistent with the $\mathrm{Fe}^{2+}$ profiles (Fig. 3). At the below-OMZ-seep, $\mathrm{Mn}^{2+}$ was present at the SWI $(\sim 3 \mu \mathrm{M})$ closest to the central habitat of active gas seepage, but concentrations were lower $(\sim 0.4 \mu \mathrm{M}) 50 \mathrm{~cm}$ away at the SWI within the clam field (Fig. 4). 


\subsection{Proxy ratios}

\subsubsection{Alteration and oxygenation proxies (HPA, API, DOXI)}

Along the OMZ transect, HPA (Table 3) values decreased from 0.58 (OMZ-hypoxic) to 0.42 (OMZ-oxic). Along the below-OMZ-seep, the index decreased from 0.67 (belowOMZ-seep 1) to 0.55 (below-OMZ-seep 3). At the OMZseep, the index values ranged from $0.6-0.73$ with no apparent trend (Table 4).

Along the OMZ transect, the API (Table 3) values decreased from 0.47 (OMZ-hypoxic) to 0.18 (OMZ-oxic). At the below-OMZ-seep, the ratio values also decreased from 0.56 to 0.37 with increasing distance from the active venting. Values at the OMZ-seep were higher in general (0.61-0.72), but showed no specific trend (Table 4).

The DOXI (Table 3) increased along the OMZ transect from 0.12 (OMZ-hypoxic) to 0.53 (OMZ-oxic). Along the below-OMZ-seep, DOXI also increased from 0.26 (belowOMZ-seep 1) to 0.41 (below-OMZ-seep 3). At the OMZseep, DOXI varied between $0.25-0.29$. When it was possible to calculate the ratio using the $\mathrm{C}_{32} 1,15$-diol and keto-ol, values were similar to the $\mathrm{C}_{30}$ ratios (Table 4). In the samples OMZ-oxic, below-OMZ-seep 2 and below-OMZ-seep 3, the $\mathrm{C}_{32}$ 1,15-diol was not present in high enough abundance to calculate the DOXI.

\subsubsection{Export production proxies (phytol, cholesterol, dinosterol indices, and dinoflagellate cysts)}

Along the OMZ transect, the phytol indices (Table 3) containing pristane, i.e. index ${ }^{1}$ and index ${ }^{3}$, remained around 0.25 and 0.15 , respectively (Table 4). Phytane-containing index ${ }^{2}$ values were between $0.080-0.16$ and showed no apparent trend. At both the OMZ-seep and below-OMZ-seep, ratio values were generally higher overall, especially in the samples closest to active venting (Table 4). At the below-OMZseep, all index values showed a decrease. Index ${ }^{1}$ decreased from 0.51 (below-OMZ-seep 1) to 0.25 (below-OMZ-seep 3 ), index ${ }^{2}$ from 0.2 to 0.1 , and index ${ }^{3}$ values decreased from 0.32 to 0.15 . Values of index ${ }^{1}$ at the OMZ-seep began extremely high (1.26; OMZ-seep 1) and decreased to 0.47 (OMZ-seep 3) while index ${ }^{3}$ decreased from 0.99 to 0.32 . Index ${ }^{2}$ showed less of a decrease from 0.28 to 0.15 (Table 4).

The cholesterol-based stanol/stenol index (Table 3) showed an increase along the OMZ transect from about 0.23 (OMZ-hypoxic) to 0.82 (OMZ-oxic). An increasing trend (0.37 to 0.75 ) was also apparent along the below-OMZ-seep. At the OMZ-seep, values ranged between 0.4-0.61 (Table 4).

The dinosterol-based index values increased along the OMZ transect ( 0.02 to 0.24$)$ and the below-OMZ-seep ( 0.03 to 0.26 ), and decreased along the OMZ-seep (0.18-0.06) (Table 4).
The $\mathrm{G} / \mathrm{P}$ ratio derived from dinoflagellate cysts (Table 3 ) increased from 0.13 to 0.52 along the $\mathrm{OMZ}$ transect and from 0.15 to 0.44 along the below-OMZ-seep. The ratio was consistent (0.17-0.18) at the OMZ-seep (Table 4).

\subsubsection{Temperature proxy (GDGT-based)}

The TEX $_{86}$ index decreased slightly from 0.75 (OMZhypoxic, OMZ-suboxic) to 0.72 (OMZ-oxic) along the OMZ transect. The corresponding SSTs show a decreased from 34.6 to $31.7^{\circ} \mathrm{C}$. $\mathrm{TEX}_{86}$ decreased more significantly along the below-OMZ-seep from 0.76 (below-OMZ-seep 1) to 0.69 (below-OMZ-seep 3). The calculated SSTs decreased from 35.6 to $29.2^{\circ} \mathrm{C}$. Along the OMZ-seep, $\mathrm{TEX}_{86}$ ranged from $0.71-0.75$, with resulting SSTs between $31.0-34.9^{\circ} \mathrm{C}$. $\mathrm{TEX}_{86}^{L}$ showed no clear trends along any of the transects and the index values ranged from -0.33 (below-OMZ-seep 2 and 3) to -0.28 (OMZ-seep 3). Subsequent SSTs varied from $24.3{ }^{\circ} \mathrm{C}$ (below $\mathrm{OMZ}$ seep-2) to $28.3^{\circ} \mathrm{C}$ (OMZ-seep $3)$. Along the OMZ transect and below-OMZ-seep, TEX ${ }_{86}^{H}$ values slightly decreased from -0.12 to -0.15 and -0.12 to -0.16 , respectively. This resulted in SSTs for the two transects of $30.1-28.6^{\circ} \mathrm{C}$, and $30.6-27.4^{\circ} \mathrm{C}$. The OMZ-seep showed a slight increase $(-0.15$ to -0.12$)$ and subsequent increase (28.7 to $30.3^{\circ} \mathrm{C}$ ) in $\mathrm{TEX}_{86}^{H}$ and SST, respectively (Table 4).

\section{Discussion}

\subsection{Lateral oxygen gradients}

Two of the investigated transects are characterized by differences in the oxygen content at the SWI and thus have the potential to exhibit an overprint on the proxy ratios as a result of selective aerobic degradation. The oxygen gradient at the SWI through the OMZ is evident based on the actual concentrations at the SWI and the oxygen penetration depth (Fig. 3) and well-known from other studies (e.g., Breuer et al., 2009). This confirms our initial classification (Table 1) based on the CTD profiling of the water column (Fig. 1b) and sediment descriptions (Bohrmann et al., 2008). As there was a very small amount of oxygen measured in the bottom waters at OMZ-hypoxic, we did not classify it as anoxic. However, we distinguished it from OMZ-suboxic, where the bottom water oxygen concentration is one order of magnitude higher. This same logic applies to the classification of the OMZ-seep, located at the lower transition of the OMZ. The CTD measurement of the deep water at the OMZ-seep station $\left(\mathrm{O}_{2}\right.$ value of $0.07 \mathrm{mll}^{-1}[\sim 3 \mu \mathrm{M}]$; Fig. 1b) is close to that measured for OMZ-hypoxic, so all samples were classified as hypoxic (Table 1). However, we note that while the OMZ-seep central habitat contained a microbial mat, indicating anoxia, the presence of small vesicomyid clams further away from the gas orifice does suggest that $\mathrm{O}_{2}$ concentrations were high 
Table 4. Proxy values of the calculated indices along the three studied transects. Definitions of each of the listed indices can be found in Table 3.

\begin{tabular}{|c|c|c|c|c|c|c|c|c|c|}
\hline & \multicolumn{3}{|c|}{ OMZ transect } & \multicolumn{3}{|c|}{ Below OMZ seep } & \multicolumn{3}{|c|}{ OMZ seep } \\
\hline & $\begin{array}{l}\text { OMZ- } \\
\text { hypoxic } \\
\text { (hypoxic) }\end{array}$ & $\begin{array}{l}\text { OMZ- } \\
\text { suboxic } \\
\text { (suboxic) }\end{array}$ & $\begin{array}{l}\text { OMZ-oxic } \\
\text { (oxic) }\end{array}$ & $\begin{array}{l}\text { below-OMZ- } \\
\text { seep } 1 \\
\text { (hypoxic) }\end{array}$ & $\begin{array}{l}\text { below-OMZ- } \\
\text { seep } 2 \\
\text { (suboxic) }\end{array}$ & $\begin{array}{l}\text { below-OMZ- } \\
\text { seep } 3 \\
\text { (oxic) }\end{array}$ & $\begin{array}{l}\text { OMZ-seep } 1 \\
\text { (hypoxic) }\end{array}$ & $\begin{array}{l}\text { OMZ-seep } 2 \\
\text { (hypoxic) }\end{array}$ & $\begin{array}{l}\text { OMZ-seep } 3 \\
\text { (hypoxic) }\end{array}$ \\
\hline \multicolumn{10}{|l|}{ Alteration indices } \\
\hline HPA & 0.58 & 0.52 & 0.42 & 0.67 & 0.65 & 0.55 & 0.68 & 0.73 & 0.6 \\
\hline API & 0.47 & 0.39 & 0.18 & 0.56 & 0.49 & 0.37 & 0.61 & 0.72 & 0.67 \\
\hline DOXI: & & & & & & & & & \\
\hline $\mathrm{C}_{30}$ isomer & 0.12 & 0.24 & 0.53 & 0.26 & 0.37 & 0.41 & 0.28 & 0.26 & 0.25 \\
\hline $\mathrm{C}_{32}$ isomer & 0.14 & 0.22 & n.m. & 0.27 & n.m. & n.m. & 0.28 & 0.26 & n.m. \\
\hline \multicolumn{10}{|l|}{$\begin{array}{l}\text { Export production } \\
\text { indices }\end{array}$} \\
\hline \multicolumn{10}{|l|}{ Phytol-based: } \\
\hline index ${ }^{1}$ & 0.28 & 0.24 & 0.25 & 0.51 & 0.25 & 0.25 & 1.26 & 0.62 & 0.47 \\
\hline index ${ }^{2}$ & 0.16 & 0.08 & 0.15 & 0.2 & 0.1 & 0.11 & 0.28 & 0.19 & 0.15 \\
\hline index ${ }^{3}$ & 0.11 & 0.16 & 0.15 & 0.32 & 0.2 & 0.15 & 0.99 & 0.43 & 0.32 \\
\hline Stanol/stenol & 0.23 & 0.24 & 0.82 & 0.37 & 0.59 & 0.75 & 0.54 & 0.61 & 0.4 \\
\hline Dinosterol-based & 0.02 & 0.05 & 0.24 & 0.03 & 0.21 & 0.26 & 0.18 & 0.09 & 0.06 \\
\hline $\mathrm{G} / \mathrm{P}$ & 0.13 & 0.31 & 0.52 & 0.15 & 0.3 & 0.44 & 0.17 & 0.18 & 0.18 \\
\hline \multicolumn{10}{|l|}{$\begin{array}{l}\text { Temperature } \\
\text { indices* }\end{array}$} \\
\hline${ }^{\mathrm{a}} \mathrm{TEX}_{86}$ & $\begin{array}{l}0.75 \\
\left(34.6^{\circ} \mathrm{C}\right)\end{array}$ & $\begin{array}{l}0.75 \\
\left(34.7^{\circ} \mathrm{C}\right)\end{array}$ & $\begin{array}{l}0.72 \\
\left(31.7^{\circ} \mathrm{C}\right)\end{array}$ & $\begin{array}{l}0.76 \\
\left(35.6^{\circ} \mathrm{C}\right)\end{array}$ & $\begin{array}{l}0.73 \\
\left(32.7^{\circ} \mathrm{C}\right)\end{array}$ & $\begin{array}{l}0.69 \\
\left(29.2^{\circ} \mathrm{C}\right)\end{array}$ & $\begin{array}{l}0.72 \\
\left(31.7^{\circ} \mathrm{C}\right)\end{array}$ & $\begin{array}{l}0.71 \\
\left(31.0^{\circ} \mathrm{C}\right)\end{array}$ & $\begin{array}{l}0.75 \\
\left(34.9^{\circ} \mathrm{C}\right)\end{array}$ \\
\hline${ }^{\mathrm{b}} \mathrm{TEX}_{86}^{L}$ & $\begin{array}{l}-0.29 \\
\left(27.5^{\circ} \mathrm{C}\right)\end{array}$ & $\begin{array}{l}-0.32 \\
\left(25.5^{\circ} \mathrm{C}\right)\end{array}$ & $\begin{array}{l}-0.29 \\
\left(27.2^{\circ} \mathrm{C}\right)\end{array}$ & $\begin{array}{l}-0.3 \\
\left(26.8^{\circ} \mathrm{C}\right)\end{array}$ & $\begin{array}{l}-0.33 \\
\left(24.3^{\circ} \mathrm{C}\right)\end{array}$ & $\begin{array}{l}-0.33 \\
\left(24.6^{\circ} \mathrm{C}\right)\end{array}$ & $\begin{array}{l}-0.3 \\
\left(26.7^{\circ} \mathrm{C}\right)\end{array}$ & $\begin{array}{l}-0.29 \\
\left(27.0^{\circ} \mathrm{C}\right)\end{array}$ & $\begin{array}{l}-0.28 \\
\left(28.3^{\circ} \mathrm{C}\right)\end{array}$ \\
\hline${ }^{\mathrm{c}} \mathrm{TEX}_{86}^{H}$ & $\begin{array}{l}-0.12 \\
\left(30.1^{\circ} \mathrm{C}\right)\end{array}$ & $\begin{array}{l}-0.12 \\
\left(30.2^{\circ} \mathrm{C}\right)\end{array}$ & $\begin{array}{l}-0.15 \\
\left(28.6^{\circ} \mathrm{C}\right)\end{array}$ & $\begin{array}{l}-0.12 \\
\left(30.6^{\circ} \mathrm{C}\right)\end{array}$ & $\begin{array}{l}-0.14 \\
\left(29.2^{\circ} \mathrm{C}\right)\end{array}$ & $\begin{array}{l}-0.16 \\
\left(27.4^{\circ} \mathrm{C}\right)\end{array}$ & $\begin{array}{l}-0.15 \\
\left(28.7^{\circ} \mathrm{C}\right)\end{array}$ & $\begin{array}{l}-0.15 \\
\left(28.3^{\circ} \mathrm{C}\right)\end{array}$ & $\begin{array}{l}-0.12 \\
\left(30.3^{\circ} \mathrm{C}\right)\end{array}$ \\
\hline
\end{tabular}

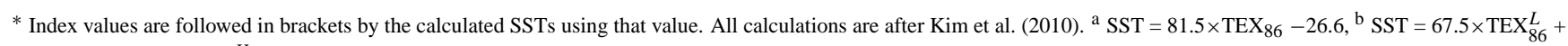
$46.9,{ }^{\mathrm{c}} \mathrm{SST}=68.4 \times \mathrm{TEX}_{86}^{H}+38.6$. n.m. $=$ not measurable.

enough to support them (e.g., Fischer et al., 2011). Therefore, it is likely that a lateral oxygen gradient is present at the OMZ-seep; however, the magnitude of this gradient must be smaller than along the OMZ transect or the below-OMZseep.

The presence of a distinct spatially short-scale oxygen gradient at the below-OMZ-seep was initially inferred from the differences in fluid/gas flow and colonization by chemosynthetic communities of the seep habitats (Bohrmann et al., 2008; Fischer et al., 2011). The pore water manganese $\left(\mathrm{Mn}^{2+}\right)$ profiles (Fig. 4) corroborate this, indicating oxygen was either absent or present in very low concentrations at below-OMZ-seep 1 and higher at below-OMZ-seep 2. Mnoxides are stable under oxic conditions and begin to dissolve as soon as the environment becomes reducing (Saager et al., 1989; Schenau et al., 2002; van der Weijden et al., 2006). So, the absence of $\mathrm{Mn}^{2+}$ in the uppermost sediments can be used as an oxygen indicator. Subsequently, the below-OMZ-seep samples are classified as follows: below-OMZ-seep 1 as hypoxic, below-OMZ-seep 2 as suboxic, and below-OMZ-seep 3 as oxic (Table 1). Below-OMZ-seep 3 was classified as oxic since it is furthest from the central gas orifice and more likely influenced by the bottom water oxygen content of the surrounding area.
This study investigated the correlation between increasing oxygen concentrations and changes in proxy ratios; however, there are other factors related to the oxygen concentration that can also have an effect. A variety of organisms live within marine sediments and influence the OM composition through processes such as bioturbation and bioirrigation (Cowie and Levin, 2009 and references therein). These effectively increase the amount of time the sediments are exposed to bottom water oxygen (e.g., van der Weijden et al., 1999). Therefore, our observed proxy trends represent not just the effects of bottom water oxygen concentrations per se but also how these concentrations influence the extent of benthic faunal activity and, thus, the overall amount of time that the surface sediments are exposed to oxygen.

\subsection{Alteration and oxygenation proxies (HPA, API, DOXI)}

\subsubsection{HPA}

In the transects incorporating lateral oxygen gradients, the HPA ratios decrease by almost $30 \%$ (OMZ transect) and $20 \%$ (below-OMZ-seep) with increasing oxygen concentrations (Fig. 5a). In comparison, there was no change observed along the OMZ-seep (Fig. 5a). These trends are the result of preferential degradation of the $n$-alcohols, which are 

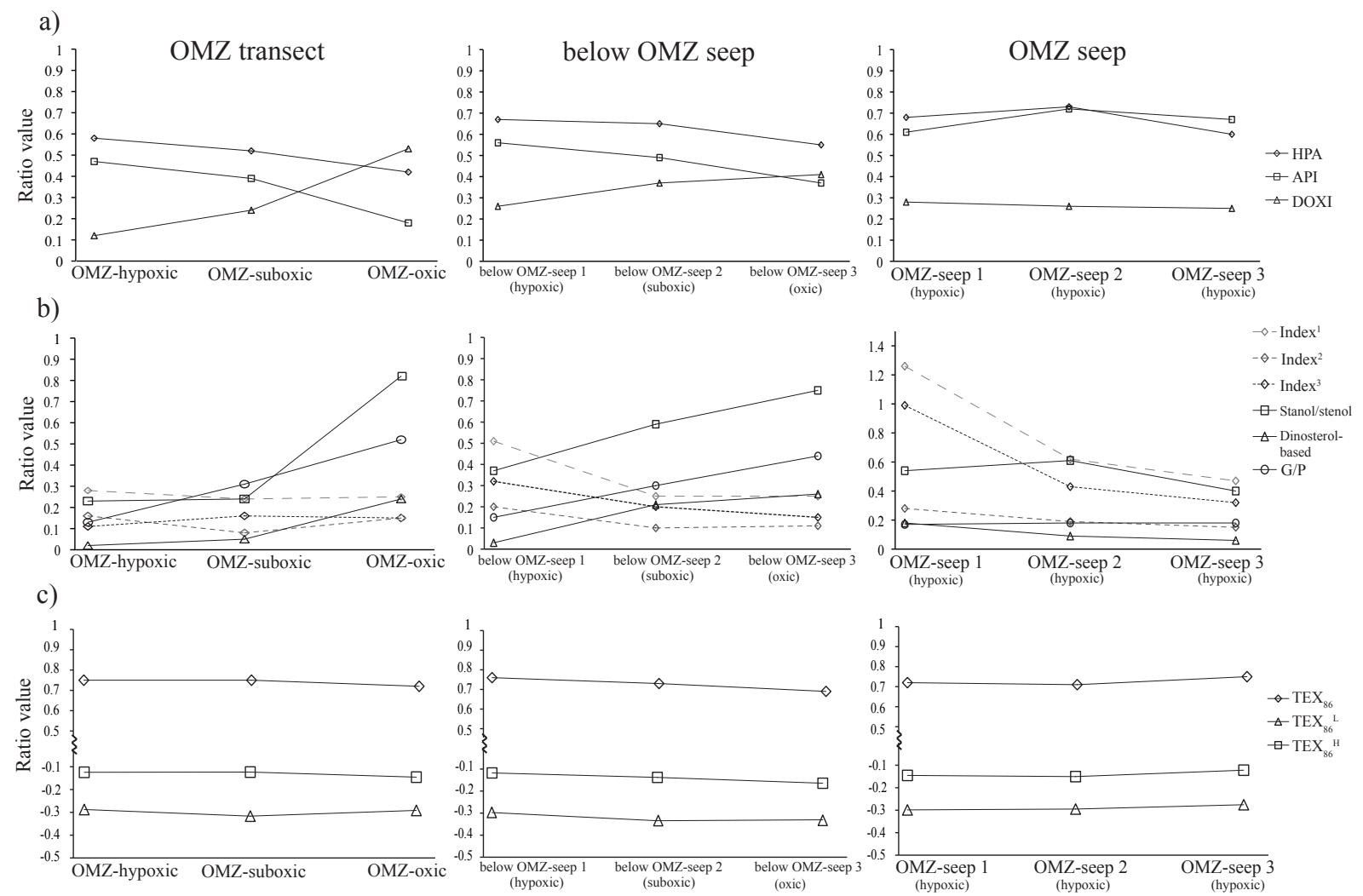

Fig. 5. Proxy ratio trends along the three studied transects of the OMZ transect, below-OMZ-seep, and OMZ-seep, showing (a) alteration indices, (b) export production proxies, and (c) temperature proxies. Note that the scale in (b) export production proxies of the OMZ-seep transect differs from the other transects.

more labile than the $n$-alkanes (e.g., Yamamoto et al., 2008). Since these trends are similar along the long OMZ transect and the short below-OMZ-seep, the ratio values cannot result from degradation en route to the marine realm (i.e. "predegradation") or during settling through the water column, and confirm the conclusions of Westerhausen et al. (1993). The similarity in HPA trends along both lateral oxygen gradients indicate that the major factor is an oxygen effect, and suggests that this index may be a useful and sensitive proxy to determine redox changes at the SWI.

\subsubsection{API}

The API provides very clear evidence for selective aerobic degradation at the SWI (Fig. 5a). The index decreased by more than $60 \%$ along the OMZ transect and more than $30 \%$ along the below-OMZ-seep, whereas no trend was visible along the OMZ-seep. In the studies of Cacho et al. (2000) and Martrat et al. (2007) where this ratio was used to reflect bottom water oxygenation changes in sediment cores, environmental heterogeneity, such as fluctuations in terrestrial input over time, could not be discounted as a variable possibly affecting the proxy. The short lateral oxygen transect at below-OMZ-seep effectively eliminates that uncertainty.
In our data, this ratio appears to be effective as a sensitive bottom water oxygen indicator at the SWI. Thus, we suggest that it is a possible proxy for oxygenation changes in surface samples.

\subsubsection{DOXI}

This index reflects significant selective aerobic degradation, as a five-fold increase is present in the along the OMZ transect and a doubling along the below-OMZ-seep (Fig. 5a). Selective degradation of the diols relative to the keto-ols has previously been used to distinguish between the oxidized and unoxidized portions of the Mediterranean S1 sapropel (Ferreira et al., 2001; Versteegh et al., 2010). However, this is the first indication that this proxy is also able to reflect redox changes at the SWI. Ferreira et al. (2001) noted that the absolute concentrations of keto-ols increased as the diol concentrations decreased. They proposed that the keto-ols could be an oxidative product of the diols. In our samples, the relative concentration of the keto-ols increased as well (see Supplement), which further supports the idea that they are oxidation products of the diols. $\mathrm{C}_{28}-\mathrm{C}_{32}$ keto-ols were identified in a cultured marine eustimatophyte, Nannochloropsis gaditana (Méjanelle et al., 2003) and a fern species, Osmunda regalis 
(Jetter and Riederer, 1999). However, the keto-ol concentrations reported in $N$. gaditana were less than what is generally reported in marine sediments (Méjanelle et al., 2003). Likewise, the terrestrial input in our samples is much less than the marine component, as shown by the low concentrations of long chain $n$-alkanes and total pollen grains (see Supplement), so influence from vegetation should not be a major factor. Thus, even if there is a contributing factor of biosynthesized keto-ols, it is most likely a small amount and still would not be sufficient to explain the trend in the ratios along the below-OMZ-seep.

\subsection{Export production proxies (phytol, cholesterol, dinosterol indices and dinoflagellate cysts)}

\subsubsection{Phytol-based indices}

The lack of any significant trends attributable to oxygen from the three phytol-based indices indicates they do not reflect selective aerobic degradation. Instead, a secondary source appears to be overprinting two of the phytol-based indices. Index ${ }^{1}$ and index ${ }^{3}$ (Table 4; Fig. 5b) values in belowOMZ-seep 1 and OMZ-seep 1 are up to an order of magnitude higher in comparison to the non-seep influenced OMZhypoxic. In contrast, index ${ }^{2}$ values vary between $0.1-0.28$ in all samples (Fig. 5b). This contrast may thus suggest a sedimentary contribution of pristane, as it is used in the former indices but not in the latter. While pristane and phytane are generally considered compounds produced via degradation of phytol (e.g., Didyk et al., 1978), this assumption for pristane has been questioned in oxygen-depleted sediments (e.g., Grossi et al., 1998; Rontani and Volkman, 2003; Rontani et al., 2010). The higher index ${ }^{1}$ and index ${ }^{3}$ values in belowOMZ-seep 1 and OMZ-seep 1 could indicate faster conversion of reactive phytol into a more refractory form (e.g., Sun et al., 1998). If this were true, it should also be reflected in index ${ }^{2}$, where, in fact, the values are stable. Thus, it is likely that there is a secondary source of pristane that does not involve the degradation of chlorophyll- $a$ (for a review see Rontani and Bonin, 2011). Sources could include tocopherol degradation (Rontani et al., 2010) or input from archaeal lipids (Rowland, 1990). Even without the sedimentary input of pristane, index ${ }^{2}$ does not show a preferential degradation of phytol with increasing SWI oxygen concentrations. Our results agree with previous studies cautioning against the use of a proxy for redox changes based on these assumed phytol degradation products (Rontani and Volkman, 2003).

\subsubsection{Cholesterol based stanol/stenol index}

The cholestanol/cholesterol index values more than double along the OMZ transect and the below-OMZ-seep, which suggests faster degradation of cholesterol along the lateral oxygen gradients (Fig. 5b). More efficient degradation of cholesterol under oxic conditions has previously been suggested in experiments (Sun and Wakeham, 1998). However, our data contrast with those from the Peru margin OMZ, where anoxic sediments generally produced the highest values (McCaffrey et al., 1991). The reduction of cholesterol to cholestanol under anoxic conditions can be a faster process than sterol degradation, and is the main reason for high stanol/stenol ratios in anoxic waters and sediments (Nishimura and Koyama, 1977; Wakeham, 1989). However, the presence of an increasing trend along the lateral oxygen gradients suggests that the dominant process controlling this ratio is the degradation of cholesterol. So, the ratio values reflect the faster degradation of cholesterol compared to cholestanol, rather than the conversion of cholesterol to cholestanol. This is further reinforced by the lack of any trend in the overall hypoxic setting of the OMZ-seep. The higher rate of stenol degradation versus stenol hydrogenation has been suggested as one possibility to explain the high stanol/stenol surface sediment values in an estuarine environment (Arzayus and Canuel, 2004). Therefore, in sediments with a steep lateral oxygen gradient, this ratio may be useful in determining the extent of sterol oxidation.

\subsubsection{Dinosterol-based index}

The dinosterol-based index increases by an order of magnitude along the OMZ transect and the below-OMZ-seep (Fig. 5b), indicating faster degradation of dinosterol. It is unlikely that the index changes are a result of fluctuations in input from dinoflagellates, or other dinosterol-producing organisms (Volkman et al., 1993), as the trends are similar for the OMZ transect and the below-OMZ-seep. Mouradian et al. (2007) indicate that the inclusion of dinosterol diagenetic products ( $\Sigma$ dinoflagellate lipids) provide evidence of preferential removal of dinosterol in oxic environments, as the degradation of dinosterol would result in enrichments of its degradative products. Though dinostanone and dinosterone can be biosynthesized directly by dinoflagellates (e.g., Harvey et al., 1988; Leblond and Chapman, 2002; Chu et al., 2009), differences in input are again unlikely. Thus, we conclude that a dinosterol-based index using the more refractory products of dinosterol degradation can be used to trace changes in oxygen content at the SWI.

\subsubsection{G/P ratio}

Dinoflagellate cysts are, in general, relatively resistant to degradation due to the structure of the cyst wall (e.g., Kokinos et al., 1998; Gélinas et al., 2001; de Leeuw et al., 2006; Zonneveld et al., 2008; Versteegh et al., 2012). However, it is known from laboratory (e.g., Dale, 1976; Hopkins and McCarthy, 2002) and field experiments (e.g., Kodrans-Nsiah et al., 2008) as well as sediments (e.g., Zonneveld et al., 1997; 2001; 2007; McCarthy et al., 2000) that P-cysts are more quickly oxidized relative to the G-cysts. In both the OMZ 
transect and the below-OMZ-seep, the G/P ratio increases by $75 \%$ and $66 \%$, respectively (Fig. 5b). Thus, our data confirm the selective aerobic degradation of P-cysts and demonstrate a marked overprint of the original dinoflagellate cyst assemblage, which suggests that the G/P ratio is a potential proxy for tracing oxygen concentrations changes at the SWI. Previous studies have cautioned against the use of this ratio because it oversimplifies the relationship between the heterotrophic taxa that are used to indicate productivity and Pcysts (e.g., Dale and Fjellså, 1994). Our results add another layer of caution as an overprinting of the G/P ratio seems sensitive to oxidative effects in surface sediments. However, in some cases this overprint can be accounted for (Versteegh and Zonneveld, 2002) and, in areas of excellent preservation or when redox conditions remain stable over time, Pcysts are still valuable productivity proxies (e.g., Reichart and Brinkhuis, 2003).

It is interesting to note that the dinosterol-based index and the $\mathrm{G} / \mathrm{P}$ ratio demonstrated similar trends along the OMZ transect and the below-OMZ-seep. There has been some discrepancy as to the relationship between dinoflagellate cyst abundance/concentrations, and dinosterol concentrations with studies either showing a weak (e.g., Marret and Scourse, 2002) or nonexistent (Pinturier-Geiss et al., 2002; Sangiorgi et al., 2005) correlation. This may be related to differences in the species that biosynthesize dinosterol as a membrane lipid and those that produce resting cysts (Boere et al., 2009). Our results agree with Mouradian et al. (2007) that the inclusion of diagenetic transformation products of dinosterol increases the likelihood that the dinosterol-based index and dinoflagellate cyst trends will be similar. This may then reflect a correlation that is based on diagenetic factors, rather than productivity.

\subsection{Temperature proxy (GDGT-based)}

The overall small changes in the three GDGT-based indices (Fig. 5c) and the fact that none could be attributed to an oxygen effect indicate that the GDGT distribution is not affected by selective aerobic degradation. Instead, it appears the GDGT signal is complicated by different factors in each transect, as the $\mathrm{TEX}_{86}$ values and resulting SSTs are variable. SSTs calculated from these indices do not consistently reflect the annual mean SST $\left(26.7^{\circ} \mathrm{C}\right)$ as recorded by Lornacini et al. (2010). $\mathrm{TEX}_{86}$ values are higher than previously reported for the Arabian Sea (e.g., Schouten et al., 2002, 2004; Kim et al., 2008), and result in unrealistically high SSTs. The same is true for the $\mathrm{TEX}_{86}^{H}$, which was shown to be suitable in subtropical waters (Kim et al., 2010). The most similar calculated SST to the reported SST of the area is derived from the $\mathrm{TEX}_{86}^{L}$, which is considered particularly appropriate for (sub) polar waters (Kim et al., 2010). The difference between the three indices is the absence of the crenarcheaol regioisomer in the $\mathrm{TEX}_{86}^{L}$, which suggests a deviation from its observed correlation with SST at high temperatures (Kim et al., 2010), and indicates that this index may not necessarily be limited to the reconstruction of lower temperatures (Ho et al., 2011). The crenarchaeol regioisomer has been suggested to have a different source than the other GDGTs (see the discussion in Shah et al., 2008). It was pointed out in Shah et al. (2008) that this could have implications for the $\mathrm{TEX}_{86}$ paleothermometer, which our data illustrate. However, the GDGT indices seem to show no clear trends that might suggest differential input of the crenarchaeol regioisomer.

Other complicating factors could include a strong seasonal signal (Wuchter et al., 2006; Leider et al., 2010), or sedimentary production in anoxic sediments (e.g., Pancost et al., 2001; Biddle et al., 2006; Lipp et al., 2008) so that our data may reflect differential GDGT contributions from the water column (surface and subsurface; e.g., Huguet et al., 2007; Mollenhauer et al., 2008) as well as the seep environment. However, the lack of any consistency between the OMZ-seep and the below-OMZ-seep would suggest that the two seep transect communities are heterogeneous. Zhang et al. (2011) suggest that in environments heavily impacted by methane hydrates, the contribution of GDGTs produced by methanotrophic archaea render the $\mathrm{TEX}_{86}$ index unreliable. However, in our data, it appears that the crenarcheaol regioisomer is the main source of variability as the $\mathrm{TEX}_{86}^{L}$ produces the most realistic SSTs. Overall, we cannot determine which possible factors have the most influence but it seems likely that the three transects used in this study reflect heterogeneous GDGT input from the water column and the sediments, which reflects a significant effect of local conditions.

\section{Conclusions}

The OMZ and active methane seeps of the northeastern Arabian Sea present a natural laboratory to investigate the effects of oxygen on proxy values at the SWI. Our study focused on the effects detailed by two lateral oxygen gradients, one of which was approximately a meter long, on alteration, export production, and temperature proxies in surface samples. In order to constrain the effects of additional environmental conditions, we utilized samples transecting the OMZ, as well as methane seeps, in oxic and hypoxic bottom waters. A demonstrated increase in the oxygen concentration at the SWI was shown to affect most of the investigated proxy ratios with the exception of the GDGT- and phytol-based indices, where localized and secondary sources of input were more important.

The HPA, API, and DOXI, previously used in sediment core studies as alteration and oxygenation proxies, appear also to be quite sensitive to changing oxygen conditions at the SWI. Because these three proxies demonstrate a high sensitivity, they may be appropriate to use in further studies regarding changing oxygen conditions. The degradation of cholesterol at a well-oxygenated SWI seems to be faster than the reductive transformation of cholesterol to cholestanol, so 
that a stanol/stenol index may also be a useful proxy for changes in oxygen content. Likewise, a degradation index based on dinosterol and its transformational products and the dinoflagellate cyst-based G/P index might be useful to show redox changes in surface sediments. Our data demonstrate that even a small, localized lateral oxygen gradient at the SWI is sufficient to induce selective OM degradation and provides further evidence that care must be taken in order to accurately interpret the sedimentary record.

\section{Supplementary material related to this article is available online at: http://www.biogeosciences.net/9/ 1553/2012/bg-9-1553-2012-supplement.pdf.}

Acknowledgements. We appreciate the efforts of the captain and crew of the R/V Meteor cruise M74/3, as well as the ROV "MARUM-QUEST 4000" team (MARUM, Bremen) for their excellent support during the cruise. We also thank S. Forke, G. Greif, and R. Himmelsbach for laboratory assistance. X. Liu was kind enough to perform the GDGT analysis. We thank the constructive criticism of two anonymous reviewers and the editor ( $\mathrm{J}$. Middelburg), whose comments improved this manuscript. Financial support was provided by the DFG-Research Center/Excellence Cluster MARUM “The Ocean in the Earth System", and the DFG (Deutsche Forschungsgemeinschaft) as part of the International Graduate College "Proxies in Earth History" (EUROPROX), as well as the Helmholtz group and a Heisenberg Fellowship (VE-486/2 and /3) to GJMV.

Edited by: J. Middelburg

\section{References}

Aharon, P. and Fu, B.: Microbial sulfate reduction rates and sulfur and oxygen isotope fractionations at oil and gas seeps in deepwater Gulf of Mexico, Geochim. Cosmochim. Acta, 64, 233-246, 2000.

Aharon, P., and Fu, B.: Sulfur and oxygen isotopes of coeval sulfate-sulfide in pore fluids of cold seep sediments with sharp redox gradients, Chem. Geol., 195, 201-218, 2003.

Arzayus, K. M. and Canuel, E. A.: Organic matter degradation in sediments of the York River estuary: Effects of biological vs. physical mixing, Geochim. Cosmochim. Acta, 69, 455-463, 2004.

Barrett, S., Volkman, J. K., and Dunstan, G. A.: Sterols of 14 species of marine diatoms (Bacillariophyta), J. Phycol., 31, 360369, 1995.

Bauer, S., Hitchcock, J. L., and Olson, D. B.: Influence of monsoonally-forced Ekman dynamics upon surface layer depth and plankton biomass distribution in the Arabian Sea, Deep Sea Res., 38, 531-553, 1991.

Biddle, J. F., Lipp, J. S., Lever, M. A., Lloyd, K. G., Sørensen, K. B., Anderson, R., Fredericks, H. F., Elvert, M., Kelly, T. J., Schrag, D. P., Sogin, M. L., Brenchley, J. E., Teske, A., House, C. H., and Hinrichs, K.-U.: Heterotrophic Archaea dominate sedimentary subsurface ecosystems off Peru, Proc. Nat. Acad. Sci., 103, 3846-3851, 2006.
Bockelmann, F., Zonneveld, K. A. F., and Schmidt, M.: Assessing environmental control on dinoflagellate cyst distribution in surface sediments of the Benguela upwelling region (eastern South Atlantic), Limnol. Oceanogr. 52, 2582-2594, 2007.

Boere, A. C., Abbas, B., Rijpstra, W. I. C., Versteegh, G. J. M., Volkman, J. K., Sinninghe Damsté, J. S., and Coolen, M. J. L.: Late-Holocene succession of dinoflagellates in an Antarctic fjord using a multi-proxy approach: palaeoenvironmental genomics, lipid biomarkers and palynomorphs, Geobiology, 7, 265-281, 2009.

Bohrmann, G., Bahr, A., Brinkmann, F., Brüning, M., Buhmann, S., Diekamp, V., Enneking, K., Fischer, D., Gassner, A., von Halem, G., Huettich, D., Kasten, S., Klapp, S., Nasir, M., Nowald, N., Ochsenhirt, W. T., Pape, T., Ratmeyer, V., Rehage, R., Rethemeyer, J., Reuter, M., Rossel, P., Saleem, M., Schmidt, W., Seiter, C., Stephan, S., Thomanek, K., Wittenberg, N., Yoshinaga, M., and Zonneveld, K.: Report and preliminary results of R/V Meteor cruise M74/3, Fujairah-Malé, 30 October7 November, 2007, Cold seeps of the Makran subduction zone (Continental margin off Pakistan), Berichte, Fachbereich 5, Universität Bremen, edited by: Bohrmann, G. and Ohling, G., Bremen, Germany, 161 pp., 2008.

Boon, J. J., Rijpstra, W. I. C., de Lange, F., and de Leeuw, J. W.: Black Sea sterol - a molecular fossil for dinoflagellate blooms, Nature, 277, 125-126, 1979.

Brand, T. D. and Griffiths, C.: Seasonality in the hydrography and biogeochemistry across the Pakistan Margin of the NE Arabian Sea, Deep Sea Res. Part II, 56, 283-295, 2009.

Breuer, E. R., Law, G. T. W., Woulds, C., Cowie, G. L., Shimmield, G. B., Peppe, O., Schwartz, M., and McKinlay, S.: Sedimentary oxygen consumption and microdistribution at sites across the Arabian Sea oxygen minimum zone (Pakistan margin), Deep Sea Res. Part II, 56, 296-304, 2009.

Cacho, I., Grimalt, J. O., Sierro, F. J., Shackleton, N., and Canals, M.: Evidence for enhanced Mediterranean thermohaline circulation during rapid climatic coolings, Earth Planet. Sci. Lett., 183, 417-429, 2000.

Calvert, S. E., Pedersen, T. F., Naidu, P. D., and von Stackelburg, U.: On the organic carbon maximum on the continental slope of the eastern Arabian Sea, J. Mar. Res., 53, 279-296, 1995.

Canfield, D. E., Thamdrup, B., and Hansen, J. W.: The anaerobic degradation of organic matter in Danish coastal sediments: iron reduction, manganese reduction, and sulphate reduction, Geochim. Cosmochim. Acta, 57, 3867-3883, 1993.

Canuel, E. A. and Martens, C. S.: Reactivity of recently deposited organic matter: Degradation of lipid compounds near the sediment-water interface, Geochim. Cosmochim. Acta, 60, 1793-1806, 1996.

Chu, F. L. E., Lund, E. D., Littreal, P. R., Ruck, K. E., and Harvey, E.: Species-specific differences in long-chain n-3 essential fatty acid, sterol, and steroidal ketone production in six heterotrophic protist species, Aquat. Biol., 6, 159-172, 2009.

Combourieu-Nebout, N., Paterne, M., Turon, J. L., and Siani, G.: A high-resolution record of the last deglaciation in the central Mediterranean Sea: Palaeovegetation and palaeohydrological evolution, Quat. Sci. Rev., 17, 303-317, 1998.

Cowie, G. L. and Levin, L. A.: Benthic biological and biogeochemical patterns and processes across an oxygen minimum zone (Pakistan margin, NE Arabian Sea), Deep Sea Res. Part II, 56, 261- 
270,2009

Cowie, G. L., Hedges, J. L., Prahl, F. G., and de Lange, G. J.: Elemental and major biochemical changes across an oxidation front in a relict turbidite: an oxygen effect, Geochim. Cosmochim. Acta, 59, 33-46, 1995.

Cowie, G. L., Calvert, S. E., Pedersen, T. F., Schulz, H., and von Rad, U.: Organic content and preservational controls in surficial shelf and slope sediments from the Arabian Sea (Pakistan Margin), Mar. Geol., 161, 23-38, 1999.

Dale, B.: Cyst formation, sedimentation, and preservation: factors affecting dinoflagellate assemblages in recent sediments from Trondheimsfjord, Norway, Rev. Palaeobot. Palynol, 22, 39-60, 1976.

Dale, B. and Fjellså, A.: Dinoflagellate cysts as paleoproductivity indicators: state of the art, potential and limits, in: Carbon Cycling in the Glacial Ocean: Constraints on the Ocean's Role in Global Change, edited by: Zahn, R., Pedersen, T. F., Kaminski, M. A., and Labeyrie, L., Springer, Berlin, 521-537, 1994.

de Leeuw, J. W., Rijpstra, W. I. C., and Schenck, P. A.: The occurrence and identification of $\mathrm{C}_{30}, \mathrm{C}_{31}$, and $\mathrm{C}_{32}$ alkan-1,15-diols and alkan-15-one-1-ols in Unit I and Unit II Black Sea sediments, Geochim. Cosmochim. Acta, 45, 2281-2285, 1981.

de Leeuw, J. W., Versteegh, G. J. M., and van Bergen, P. F.: Biomacromolecules of algae and plants and their fossil analogues, Plant Ecol., 182, 209-233, 2006.

Didyk, B. M., Simoneit, B. R. T., Brassell, S. C., and Eglinton, G.: Organic geochemical indicators of paleoenvironmental conditions of sedimentation, Nature, 272, 216-222, 1978.

Ding, F., Spiess, V., Fekete, N., Murton, B., Bruening, M., and Bohrmann, G.: Interaction between accretionary thrust faulting and slope sedimentation at the frontal Makran accretionary prism and its implications for hydrocarbon fluid seepage, J. Geophys. Res., 115, B08106, doi:10.1029/2008JB006246, 2010.

Eglinton, G. and Hamilton, R. J.: Leaf epicuticular waxes, Science, 156, 1322-1335, 1967.

Fensome, R. A. and Williams, G. L.: The Lentin and Williams index of fossil dinoflagellates, 2004 Edition, Ameri. Assoc. Strat. Paly., Contributions Series 42, 909 pp., 2004.

Fensome, R. A., Taylor, F. J. R., Norris, G., Sarjeant, W. A. S., Wharton, D. I., and Williams, G. L.: A classification of fossil and living dinoflagellates, Micropaleont. Press Special Paper, 7, 351 pp., 1993.

Ferreira, A. M., Miranda, A., Caetano, M., Baas, M., Vale, C., and Sinninghe Damsté, J. S.: Formation of mid-chain alkane ketools by post-depositional oxidation of mid-chain diols in Mediterranean sapropels, Org. Geochem., 32, 271-276, 2001.

Fischer, D., Sahling, H., Nöthen, K., Bohrmann, G., Zabel, M., and Kasten, S.: Interaction between hydrocarbon seepage, chemosynthetic communities and bottom water redox at cold seeps of the Makran accretionary prism: insights from habitatspecific pore water sampling and modeling, Biogeosci. Discuss., 8, 9763-9811, doi:10.5194/bgd-8-9763-2011, 2011.

Fukushima, K. and Ishiwatari, R.: Acid and alcohol compositions of wax esters in sediments from different environments, Chem. Geol., 47, 41-56, 1984.

Gélinas, Y., Baldock, J. A., and Hedges, J. I.: Organic carbon composition of marine sediments: effect of oxygen exposure on oil generation potential, Science, 294, 145-148 2001.
Grossi, V., Hirschler, D., Raphel, D., Rontani, J. F., de Leeuw, J. W., and Bertrand, J. C.: Biotransformation pathways of phytol in Recent anoxic sediments, Org. Geochem., 29, 845-861, 1998.

Grossi, V., Blokker, P., and Sinninghe Damsté, J. S.: Anaerobic biodegradation of lipids of the marine microalga Nannochloropsis salina, Org. Geochem., 32, 795-808, 2001.

Harland, R.: Dinoflagellate cysts and acritarchs from the Bearpaw Formation (upper Campanian) of southern Alberta, Canada, Paleontol., 16, 665-706, 1973.

Hartnett, H. E., Keil, R. G., Hedges, J. I., and Devol, A. H.: Influence of oxygen exposure time on organic carbon preservation in continental margin sediments, Nature, 391, 572-574, 1998.

Harvey, H. R., Bradshaw, S. A., O'Hara, S. C. M., Eglinton, G., and Corner, E. D. S.: Lipid composition of the marine dinoflagellate Scrippsiella trochoidea, Phytochem., 27, 1723-1729, 1988.

Hedges, J. I. and Keil, R. G.: Sedimentary organic matter preservation: an assessment and speculative synthesis, Mar. Chem., 49, 81-115, 1995.

Hedges, J. I., Hu, F. S., Devol, A. H., Hartnett, H. E., Tsamakis, E., and Keil, R. G.: Sedimentary organic matter preservation: a test for selective degradation under oxic conditions, Amer. J. Sci., 299, 529-555, 1999.

Henrichs, S. M.: Early diagenesis of organic matter in marine sediments: progress and perplexity, Mar. Chem., 39, 119-149, 1992.

Ho, S. L., Yamamoto, M., Mollenhauer, G., and Minagawa, M.: Core top $\mathrm{TEX}_{86}$ values in the south and equatorial Pacific, Org. Geochem., 42, 94-99, 2011.

Hoefs, M. J. L., Rijpstra, W. I. C., and Sinninghe Damsté, J. S.: The influence of oxic degradation on the sedimentary biomarker record I: Evidence from Madeira Abyssal Plain turbidites, Geochim. Cosmochim. Acta, 66, 2719-2735, 2002.

Holzwarth, U., Esper, O., and Zonneveld, K.: Distribution of organic-walled dinoflagellate cysts in sediments of the Benguela upwelling system in relationship to environmental conditions, Mar. Micropaleontol., 64, 91-119, 2007.

Hopkins, J. A. and McCarthy, F. M. G.: Post-depositional palynomorph degradation in Quaternary shelf sediments: a laboratory experiment studying the effects of progressive oxidation, $\mathrm{Pa}$ lynol., 26, 167-184, 2002.

Hopmans, E. C., Schouten, S., Pancost, R., van der Meer, M. T. J., and Sinninghe Damsté, J. S.: Analysis of intact tetraether lipids in archaeal cell material and sediments by high performance liquid chromatography/atmospheric pressure chemical ionization mass spectrometry, Rapid Commun. Mass Spec., 14, 585-589, 2000.

Hudson, E. D., Parrish, C. C., and Helleur, R. J.: Biogeochemistry of sterols in plankton, settling particles and recent sediments in a cold ocean ecosystem (Trinity Bay, Newfoundland), Mar. Chem., 76, 253-270, 2001.

Huguet, C., Schimmelmann, A., Thunell, R., Lourens, L. J., Sinninghe Damsté, J. S., and Schouten, S.: A study of the TEX $_{86}$ paleothermometer in the water column and sediments of Santa Barbara Basin, California, Paleoceanogr., 22, PA3203, doi:10.10129/2006PA00131, 2007.

Huguet, C., Kim, J. H., de Lange, G. J., Sinninghe Damsté, J. S., and Schouten, S.: Effects of long term oxic degradation on the $\mathrm{U}_{37}^{K}$, TEX $_{86}$ and BIT organic proxies, Org. Geochem., 40, 1188-1194, 2009. 
Hulthe, G., Hulth, S., and Hall, P. O. J.: Effect of oxygen on the degradation rate of refractory and labile organic matter in continental margin sediments, Geochim. Cosmochim. Acta, 62, 1319-1328, 1998.

Jetter, R. and Riederer, M.: Long-chain alkanediols, ketoaldehydes, ketoalcohols and ketoalkyl esters in the cuticular waxes of Osmunda regalis fronds, Phytochem., 52, 907-915, 1999.

Jørgensen, B. B.: Mineralisation of organic-matter in the sea-bed the role of sulphate reduction, Nature, 296, 643-645, 1982.

Jørgensen, B. B., and Kasten, S.: Sulfur cycling and methane oxidation, in: Marine Geochemistry, edited by: Schulz, H. D., and Zabel, M., Springer, Heidelberg, Germany, 263-282, 2006.

Karner, M. B., DeLong, E. F., and Karl, D. M.: Archaeal dominance in the mesopleagic zone of the Pacific Ocean, Nature, 409, 507509, 2001.

Keil, R. G. and Cowie, G. L.: Organic matter preservation through the oxygen-deficient zone of the NE Arabian Sea as discerned by organic carbon:mineral surface area ratios, Mar. Geol., 161, 13-22, 1999.

Kim, J. H., Schouten, S., Hopmans, E. C., Donner, B., and Sinninghe Damsté, J. S.: Global sediment core-top calibration of the TEX $_{86}$ paleothermometer in the ocean, Geochim. Cosmochim. Acta, 72, 1154-1173, 2008.

Kim, J. H., Huguet, C., Zonneveld, K. A. F., Versteegh, G. J. M., Roeder, W., Sinninghe Damsté, J. S, and Schouten, S.: An experimental field study to test the stability of lipids used for the $\mathrm{TEX}_{86}$ and $\mathrm{U}_{37}^{K}$ palaeothermometers, Geochim. Cosmochim. Acta, 73, 2888-2898, 2009.

Kim, J. H., van der Meer, J., Schouten, S., Helmke, P., Willmott, V., Sangiorgi, F., Koç, N., Hopmans, E. C., and Sinninghe Damsté, J. S.: New indices and calibrations derived from the distribution of crenarchaeal isoprenoid tetraether lipids: Implications for past sea surface temperature reconstructions, Geochim. Cosmochim. Acta, 74, 4639-4654, 2010.

Kodrans-Nsiah, M., de Lange, G. J., and Zonneveld, K. A. F.: A natural exposure experiment on short-term species-selective aerobic degradation of dinoflagellate cysts, Rev. Palaeobot. Palynol., 152, 32-39, 2008.

Kokinos, J. P., Eglinton, T. I., Goñi, M. A., Boon, J. J., Martoglio, P. A., and Anderson, D. M.: Characterization of a highly resistant biomacromolecular material in the cell wall of a marine dinoflagellate resting cyst, Org. Geochem., 28, 265-288, 1998.

Leblond, J. D., and Chapman, P. J.: A survey of the sterol composition of the marine dinoflagellates Karenia brevis, Karenia mikimotoi, and Karlodinium micrum: distribution of sterols within other members of the class Dinophyceae, J. Phycol., 38, 670$682,2002$.

Leider, A., Hinrichs, K.-U., Mollenhauer, G., and Versteegh, G. J. M.: Core-top calibration of the lipid based $\mathrm{U}_{37}^{K^{\prime}}$ and $\mathrm{TEX}_{86}$ temperature proxies on the southern Italian shelf (SW Adriatic Sea, Gulf of Taranto), Earth Planet. Sci. Lett., 300, 112-124, 2010.

Lipp, J., Morono, Y., Inagaki, F., and Hinrichs, K.-U.: Significant contribution of Archaea to extant biomass in marine subsurface sediments, Nature, 454, 991-994, 2008.

Liu, X., Lipp, J. S., and Hinrichs, K.-.U.: Distribution of intact and core GDGTs in marine sediments, Org. Geochem., 42, 368-375, 2011.

Locarnini, R. A., Mishonov, A. V., Antonov, J. I., Boyer, T. P., Garcia, H. E., Baranova, O. K., Zweng, M. M., and Johnson, D.
R.: World Ocean Atlas 2009, Volume 1: Temperature, edited by: Levitus, S., NOAA Atlas NESDIS 68, U.S. Government Printing Office, Washington, DC, USA, 184 pp., 2010.

Lückge, A., Ercegovac, M., Strauss, H., and Littke, R.: Early diagenetic alteration of organic matter by sulfate reduction in Quaternary sediments from the northeastern Arabian Sea, Mar. Geol., 158, 1-13, 1999.

Madhupratap, M., Prasanna Kumar, S., Bhattathiri, P. M. A., Dileep Kumar, M., Raghukumar, S., Nair, K. K. C., and Ramaiah, N.: Mechanism of the biological response to winter cooling in the northeastern Arabian Sea, Nature, 384, 549-552, 1996.

Marret, F. and Scourse, J.: Control of modern dinoflagellate cyst distribution in the Irish and Celtic seas by seasonal stratification dynamics. Mar. Micropaleontol., 47, 101-116, 2002.

Martrat, B., Grimalt, J. O., Shackleton, N. J., de Abreu, L., Hutterli, M. A., and Stocker, T. F.: Four climate cycles of recurring deep and surface water destabilizations on the Iberian Margin, Science, 317, 502-507, 2007.

Matsuoka, K., Kawami, H., Nagai, S., Iwataki, M., and Takayama, H.: Re-examination of cyst motile relationships of Polykrikos kofoidii Chatton and Polykrikos schwartzii Bütschli (Gymnodiniales, Dinophyceae), Rev. Palaeobot. Palynol., 154, 79-90, 2009.

McCaffrey, M. A., Farrington, J. W., and Repeta, D. J.: The organic geochemistry of Peru margin surface sediments: II. Paleoenvironmental implications of hydrocarbon and alcohol profiles, Geochim. Cosmochim. Acta, 55, 483-498, 1991.

McCarthy, F. M. G., Gostlin, K. E., Mudie, P. J., and Scott, D. B.: Synchronous palynological changes in early Pleistocene sediments off New Jersey and Iberia, and a possible paleoceanographic explanation, Palynol., 24, 63-77, 2000.

Méjanelle, L., Sanchez-Gargallo, A., Bentaleb, I., and Grimalt, J.: Long chain n-alkyl diols, hydroxy ketones and sterols in a marine eustigmatophyte, Nannochloropsis gaditana, and in Brachionus plicatilis feeding on the algae, Org. Geochem., 34, 527-538, 2003.

Menzel, D., Hopmans, E. C., Schouten, S., and Sinninghe Damsté, J. S.: Membrane tetraether lipids of planktonic Crenarchaeota in Pliocene sapropels of the eastern Mediterranean Sea, Palaeogeogr. Palaeoclimatol. Palaeoecol., 239, 1-15, 2006.

Mollenhauer, G., Inthorn, M., Vogt, T., Zabel, M., Sinninghe Damsté, J. S., and Eglinton, T. I.: Aging of marine organic matter during cross-shelf lateral transport in the Benguela upwelling system revealed by compound-specific radiocarbon dating, Geochem. Geophys. Geosys., 8, Q09004, doi:10.1029/2007GC001603, 2007.

Mollenhauer, G., Eglinton, T. I., Hopmans, E. C., and Sinninghe Damsté, J. S.: A radiocarbon-based assessment of the preservation characteristics of crenarchaeol and alkenones from continental margin sediments, Org. Geochem., 39, 1039-1045, 2008.

Mouradian, M., Panetta, R. J., de Vernal, A., and Gélinas, Y.: Dinosterols or dinocysts to estimate dinoflagellate contributions to marine sedimentary organic matter? Limnol. Oceanogr., 52, 2569-2581, 2007.

Mudie, P. J. and Rochon, A.: Distribution of dinoflagellate cysts in the Canadian Arctic marine realm. J. Quaternary Sci., 16, 603620, 2001.

Nishimura, M. and Koyama, T.: The occurrence of stanols in various living organisms and the behavior of sterols in contemporary 
sediments, Geochim. Cosmochim. Acta, 41, 379-385, 1977.

Olson, D. B., Hitchcock, G. L., Fine, R. A., and Warren, B. A.: Maintenance of the low-oxygen layer in the central Arabian Sea, Deep Sea Res. Part II, 40, 673-685, 1993.

Pancost, R. D., Hopmans, E. C., Sinninghe Damsté, J. S., and MEDINAUT Shipboard Scientific Party: Archaeal lipids in Mediterranean cold seeps: molecular proxies for anaerobic methane oxidation, Geochim. Cosmochim. Acta, 65, 1611-1627, 2001.

Paropkari, A. L., Prakash Babu, C., and Mascarenhas, A.: A critical evaluation of depositional parameters controlling the variability of organic carbon in Arabian Sea sediments, Mar. Geol., 107, 213-226, 1992.

Paropkari, A. L., Prakash Babu, C., and Mascarenhas, A.: New evidence for enhanced preservation of organic carbon in contact with oxygen minimum zone on the western continental slope of India, Mar. Geol., 111, 7-13, 1993.

Pedersen, T. F., Shimmield, G. B., and Price, N. B.: Lack of enhanced preservation of organic matter in sediments under the oxygen minimum zone on the Oman Margin, Geochim. Cosmochim. Acta, 56, 545-551, 1992.

Pinturier-Geiss, L., Méjanelle, L., Dale, B., and Karlsen, D. A.: Lipids as indicators of eutrophication in marine coastal sediments. J. Microbiol. Methods, 48, 239-257, 2002.

Prahl, F. G., Dymond, J., and Sparrow, M. A.: Annual biomarker record for export production in the central Arabian Sea, Deep Sea Res. Part II, 47, 1581-1604, 2000.

Prasana Kumar, S., Ramaiah, N., Mangesh, G., Sarma, V. V. S. S., Muraleedharan, P. M., Raghukumar, S., Dileep Kumar, M., and Madhupratap, M.: Physical forcing of biological productivity in the Northern Arabian Sea during the Northeast Monsoon, Deep Sea Res. Part II, 48, 1115-1126, 2001.

Qasim, S. Z.: Oceanography of the northern Arabian Sea, Deep Sea Res., 29, 1041-1068, 1982.

Reichart, G. J. and Brinkhuis, H.: Late Quaternary Protoperidinium cysts as indicators of paleoproductivity in the northern Arabian Sea, Mar. Micropaleontol., 49, 303-315, 2003.

Roberts, H. H., and Carney, R. S.: Evidence of episodic fluid, gas, and sediment venting on the northern Gulf of Mexico continental slope, Econ. Geol., 92, 863-879, 1997.

Robinson, N., Eglinton, G., Brassell, S. C., and Cranwell, P.: Dinoflagellate origin for sedimentary $4 \alpha$-methylsteroids and $5 \alpha(\mathrm{H})$-stanols, Nature, 308, 439-442, 1984.

Rontani, J. F. and Volkman, J. K.: Phytol degradation products as biogeochemical tracers in aquatic environments, Org. Geochem., 34, 1-35, 2003.

Rontani, J. F. and Bonin, P.: Production of pristane and phytane in the marine environment: role of prokaryotes, Res. Microbiol., 162, 923-933, 2011.

Rontani, J. F., Nassiry, M., Michotey, V., Guasco, S., and Bonin, P.: Formation of pristane from $a$-tocopherol under simulated anoxic sedimentary conditions: A combination of biotic and abiotic degradative processes, Geochim. Cosmochim. Acta, 74, 252263, 2010

Rowland, S. J.: Production of acyclic isoprenoid hydrocarbons by laboratory maturation of methanogenic bacteria, Org. Geochem., $15,9-16,1990$.

Saager, P. M., de Baar, H. J. W., and Burkill, P. H.: Manganese and iron in Indian Ocean waters, Geochim. Cosmochim. Acta, 53, 2259-2267, 1989.
Sangiorgi, F., Fabbri, D., Comandini, M., Gabbianelli, G., Tagliavini, E.: The distribution of sterols and organic-walled dinoflagellate cysts in surface sediments of the North-western Adriatic Sea (Italy), Estuar. Coast. Shelf Sci., 64, 395-406, 2005.

Schenau, S. J., Reichart, G. J., and de Lange, G. J.: Oxygen minimum zone controlled Mn redistribution in Arabian Sea sediments during the Late Quaternary, Paleoceanogr., 17, 1058, doi:10.1029/2000PA000621, 2002.

Schouten, S., Hopmans, E. C., Schefuß, E., and Sinninghe Damsté, J. S.: Distributional variations in marine crenarchaeotal membrane lipids: a new tool for reconstructing ancient sea water temperatures? Earth Planet. Sci. Lett., 204, 265-274, 2002.

Schouten, S., Hopmans, E. C., and Sinninghe Damsté, J. S.: The effect of maturity and depositional redox conditions on archaeal tetraether lipid palaeothermometry, Org. Geochem., 35, 567571, 2004.

Schouten, S., Forster, A., Panato, E., and Sinninghe Damsté, J. S.: Towards the calibration of the $\mathrm{TEX}_{86}$ paleothermometer in ancient greenhouse worlds, Org. Geochem., 38, 1537-1546, 2007.

Schulte, S., Mangelsdorf, K., and Rullkötter, J.: Organic matter preservation on the Pakistan continental margin as revealed by biomarker geochemistry, Org. Geochem., 31, 1005-1022, 2000.

Seeberg-Elverfeldt, J., Schlüter, M., Feseker, T., and Kölling, M.: Rhizon sampling of pore waters near the sediment-water interface of aquatic systems, Limnol. Oceanogr. Methods, 3, 361371, 2005.

Shah, S. R., Mollenhauer, G., Ohkouchi, N., Eglinton, T. I., and Pearson, A.: Origins of archaeal tetraether lipids in sediments: Insights from radiocarbon analysis, Geochim. Cosmochim. Acta, 72, 4577-4594, 2008

Shapiro, G. I. and Meschanov, S. L.: Distribution of Red Sea Water and salt lens formation in the northwest Indian Ocean, Deep Sea Res., 38, 21-34, 1991.

Sinninghe Damsté, J. S., Rijpstra, W. I. C., and Reichart, G. J.: The influence of oxic degradation on the sedimentary biomarker record II. Evidence from Arabian Sea sediments, Geochim. Cosmochim. Acta, 66, 2737-2754, 2002.

Smallwood, B. J. and Wolff, G. A.: Molecular characterisation of organic matter in sediments underlying the oxygen minimum zone at the Oman Margin, Arabian Sea, Deep Sea Res. Part II, 47, 353-375, 2000.

Suess, E., Carson, B., Ritger, S. D., Moore, J. C., Jones, M. L., Kulm, L. D., and Cochrane, G. R.: Biological communities at vent sites along the subduction zone off Oregon, Biol. Soc. Wash. Bull., 6, 475-484, 1985.

Sun, M. Y. and Wakeham, S. G.: Molecular evidence for degradation and preservation of organic matter in the anoxic Black Sea Basin, Geochim. Cosmochim. Acta, 58, 3395-3406, 1994.

Sun, M. Y. and Wakeham, S. G.: A study of oxic/anoxic effects of degradation of sterols at the simulated sediment-water interface of coastal sediments, Org. Geochem., 28, 773-784, 1998.

Sun, M. Y., Wakeham, S. G., Aller, R. C., and Lee, C.: Impact of seasonal hypoxia on diagenesis of phytol and its derivatives in Long Island Sound, Mar. Chem., 62, 157-173, 1998.

van der Weijden, C. H., Reichert, G. J., and Visser, H. J.: Enhanced preservation of organic matter in sediments deposited within the oxygen minimum zone in the northeastern Arabian Sea, Deep Sea Res. Part II, 46, 807-830, 1999. 
van der Weijden, C. H., Reichart, G. J., and van Os, B. J. H.: Sedimentary trace element records over the last $200 \mathrm{kyr}$ from within and below the northern Arabian Sea oxygen minimum zone, Mar. Geol., 231, 69-88, 2006.

Versteegh, G. J. M. and Zonneveld, K. A. F.: Use of selective degradation to separate preservation from productivity, Geology, 30, 615-618, 2002.

Versteegh, G. J. M., Bosch, H. J., and de Leeuw, J. W.: Potential palaeoenvironmental information from $\mathrm{C}_{24}$ to $\mathrm{C}_{36}$ mid-chain diols, keto-ols, and mid-chain hydroxyl fatty acids: a critical review, Org. Geochem., 27, 1-13, 1997.

Versteegh, G. J. M., Jansen, J. H. F., and Schneider, R. R.: Midchain diols and keto-ols in SE Atlantic sediments: a new tool for tracing past sea surface water masses? Geochim. Cosmochim. Acta, 64, 1879-1892, 2000.

Versteegh, G. J. M., Zonneveld, K. A. F., and de Lange, G. J.: Selective aerobic and anaerobic degradation of lipids and palynomorphs in the Eastern Mediterranean since the onset of sapropel S1 deposition, Mar. Geol., 278, 177-192, 2010.

Versteegh, G. J. M., Blokker, P., Bogus, K., Harding, I., Lewis, J., Oltmanns, S., Rochon, A., and Zonneveld, K. A. F.: Infra red spectroscopy, flash pyrolysis, thermally assisted hydrolysis and methylation (THM) in the presence of tetramethylammonium hydroxide (TMAH) of cultured and sediment-derived Lingulodinium polyedrum (Dinoflagellata) cyst walls, Org. Gechem., 43, 92-102, 2012.

Volkman, J. K., and Maxwell, J. R.: Acyclic isoprenoids as biological markers, edited by: Johns, R.B., in: Biological Markers in the Sedimentary Record, Elsevier, Amsterdam, 1-46, 1986.

Volkmann, J. K., Barrett, S. M., Dunstan, G. A., and Jeffrey, S. W.: Geochemical significance of the occurrence of dinosterol and other 4-methyl sterols in a marine diatom, Org. Geochem., 20, $7-$ 15, 1993.

Volkmann, J. K., Barrett, S. M., Blackburn, S. I., Mansour, M. P., Sikes, E. L., and Gelin, F.: Microalgal biomarkers: a review of recent research developments, Org. Geochem., 29, 1163-1179, 1998.

Volkman, J. K., Rijpstra, W. I. C., de Leeuw, J. W., Mansour, M. P., Jackson, A. E., and Blackburn, S. I.: Sterols of four dinoflagellates from the genus Prorocentrum, Phytochem., 52, 659-668, 1999.

von Rad, U., Schulz, H., Ali Khan, A., Ansari, M., Berner, U., Cepek, P., Cowie, G., Dietrich, P., Erlenkeuser, H., Geyh, M., Jennerjahn, T., Lückge, A., Marchig, V., Riech, V., Rösch, H., Schäfer, P., Schulte, S., Sirocko, F., Tahir, M., and Weiss, M.: Sampling the oxygen minimum zone off Pakistan: glacialinterglacial variations of anoxia and productivity (preliminary results, SONNE 90 cruise), Mar. Geol., 125, 7-19, 1995.

von Rad, U., Rösch, H., Berner, U., Geyh, M., Marchig, V., and Schulz, H.: Authigenic carbonates derived from oxidized methane vented from the Makran accretionary prism off Pakistan, Mar. Geol., 136, 55-77, 1996.

von Rad, U., Schaaf, M., Michels, K. H., Schulz, H., Berger, W. H., and Sirocko, F.: A 5000-yr record of climate change in varied sediments from the oxygen minimum zone off Pakistan, Northeastern Arabian Sea, Quaternary Res., 51, 39-53, 1999.

Wakeham, S. G.: Reduction of stenols to stanols in particulate matter at oxic-anoxic boundaries in seawater, Nature, 342, 787-790, 1989.
Wakeham, S. G., Peterson, M. L., Hedges, J. I., and Lee, C.: Lipid biomarker fluxes in the Arabian Sea, with a comparison to the equatorial Pacific Ocean, Deep Sea Res. Part II, 49, 2265-2301, 2002.

Westerhausen, L., Poynter, J., Eglinton, G., Erlenkeuser, H., and Sarnthein, M.: Marine and terrigenous origin of organic matter in modern sediments of the equatorial East Atlantic: the $213 \mathrm{C}$ and molecular record, Deep Sea Res. Part I, 40, 1087-1121, 1993.

Witte, U. and Pfannkuche, O.: High rates of benthic carbon remineralisation in the abyssal Arabian Sea, Deep Sea Res. Part II, 47, 2785-2804, 2000.

Wuchter, C., Schouten, S., Coolen, M. J. L., and Sinninghe Damsté, J. S.: Temperature-dependent variations in the distribution of tetraether membrane lipids of marine Crenarchaeota: implications for $\mathrm{TEX}_{86}$ paleothermometry, Paleoceanogr. 19, PA4028, doi:10.1029/2004PA001041, 2004.

Wuchter, C., Schouten, S., Wakeham, S. G., and Sinninghe Damsté, J. S.: Temporal and spatial variation in tetraether membrane lipids of marine Crenarchaeota in particulate organic matter: implications for $\mathrm{TEX}_{86}$ paleothermometry, Paleoceanogr., 20, PA3013, doi:10.1029/2004PA001110, 2005.

Wuchter, C., Schouten, S., Wakeham, S. G., and Sinninghe Damsté, J. S.: Archaeal tetraether membrane lipid fluxes in the northeastern Pacific and the Arabian Sea: implications for $\mathrm{TEX}_{86}$ paleothermometry. Paleoceanogr. 21, PA4208, doi:10.1029/2006PA001279, 2006.

Wyrtki, K.: Physical oceanography of the Indian Ocean, In: Zeitschel, B., (Ed.), The Biology of the Indian Ocean, Springer, Berlin, 18-36, 1973.

Yamamoto, M., Okino, T., Sugisaki, S., and Sakamoto, T.: Late Pleistocene changes in terrestrial biomarkers in sediments from the central Arctic Ocean, Org. Geochem., 39, 754-763, 2008.

Zhang, Y. G., Zhang, C. L., Liu, X-L., Li, L., Hinrichs, K.-U., and Noakes, J. E.: Methane Index: A tetraether archaeal lipid biomarker indicator for detecting the instability of marine gas hydrates, Earth Planet. Sci. Lett., 307, 525-534, 2011.

Zonneveld, K. A. F., Versteegh, G. J. M., and de Lange, G. J.: Preservation of organic-walled dinoflagellate cysts in different oxygen regimes: a 10,000 year natural experiment, Mar. Micropaleontol., 29, 393-405, 1997.

Zonneveld, K. A. F., Versteegh, G. J. M., and de Lange, G. J.: Palaeoproductivity and post depositional aerobic organic matter decay reflected by dinoflagellate cyst assemblages of the Eastern Mediterranean S1 sapropel, Mar. Geol., 172, 181-195, 2001.

Zonneveld, K. A. F., Bockelmann, F., and Holzwarth, U.: Selective preservation of organic-walled dinoflagellate cysts as a tool to quantify past net primary production and bottom water oxygen concentrations, Mar. Geol., 237, 109-126, 2007.

Zonneveld, K. A. F., Versteegh, G. J. M., and Kodrans-Nsiah, M.: Preservation and organic chemistry of Late Cenozoic organicwalled dinoflagellate cysts: A review, Mar. Micropaleontol., 68, 179-197, 2008.

Zonneveld, K. A. F., Versteegh, G. J. M., Kasten, S., Eglinton, T. I., Emeis, K.-C., Huguet, C., Koch, B. P., de Lange, G. J., de Leeuw, J. W., Middelburg, J. J., Mollenhauer, G., Prahl, F. G., Rethemeyer, J., and Wakeham, S. G.: Selective preservation of organic matter in marine environments; processes and impact on the sedimentary record, Biogeosciences, 7, 483-511, doi:10.5194/bg-7483-2010, 2010. 